\title{
SUPPLEMENTAL JURISDICTION AND SECTION 1367: THE GASE FOR A SYMPATHETIC TEXTUALISM
}

\author{
JAMES E. PFANDER ${ }^{\dagger}$
}

\section{INTRODUCTION}

Something appears to be going badly wrong with the interpretation of 28 U.S.C. § 1367 ("section 1367"). In the nine short years since Congress enacted it as one of several "noncontroversial" provisions of the Judicial Improvements Act of 1990,' the statute that defines the supplemental jurisdiction ${ }^{2}$ of the district courts of the United

† Professor of Law, University of Illinois College of Law. Thanks to Steve Burbank, Ellen Deason, Rick Marcus, Tom Mengler, John Oakley, Tom Rowe, David Shapiro, Joan Steinman, and Jay Tidmarsh for helpful comments on earlier drafts. In suggesting the need for a sympathetic reading, I follow the lead of the drafters of section 1367 although my reading of the text departs from theirs in a number of particulars.

${ }^{1}$ See Section 310 of the Judicial Improvements Act of 1990, Pub. L. No. 101-650, 104 Stat. 5089 (codified at 28 U.S.C. $\$ 1367$ (1994)) [hereinafter section 1367]. For the text of section $\S 1367$, see infra note 43. The Judicial Improvements Act of 1990 was assembled by selecting "noncontroversial" changes from among those recommended by the Federal Courts Study Center. Abner J. Mikva \& James E. Pfander, $O_{n}$ the Meaning of Congressional Silence: Using Federal Common Law to Fill the Gap in Congress's Residual Statute of Limitations, 107 YALE L.J. 393, 398 (1997) (noting the method House Subcommittee Chairman Kastenmeier used in selecting features of the Report of the Study Committee for incorporation into an implementing bill). On the origins of section 1367, see Thomas M. Mengler et al., Congress Accepts Supreme Court's Invitation to Codify Supplemental Jurisdiction, 74 JUDICATURE 213, 213-14 (1991), and John B. Oakley, Recent Statutory Changes in the Law of Federal Jurisdiction and Venue: The Judicial Improvements Acts of 1988 and 1990, 24 U.C. DAVIS L. REV. 735, 757-63 (1991). See generally Denis F. McLaughlin, The Federal Supplemental Jurisdiction Statute: A Constitutional and Statutory Analysis, 24 ARIZ. ST. L.J. 849, 859-89 (1992).

${ }^{2}$ Before section 1367 codified them under the common label of "supplemental jurisdiction," the doctrines of "pendent" and "ancillary" jurisdiction had developed along two separate lines in the decisional law of the Supreme Court. See Owen Equip. \& Erection Co. v. Kroger, 437 U.S. 365, 370 (1978) (describing pendent and ancillary jurisdiction as "two species of the same generic problem"). For nice accounts of the separate but related development of the doctrines, see Richard D. Freer, $A$ Principled Statutory Approach to Supplemental Jurisdiction, 1987 DUKE L.J. 34, and Richard Matasar, A Pendent and Ancillary Jurisdiction Primer: The Scope and Limits of Supplemental Jurisdiction, 17 U.C. DAVIS L. REV. 103 (1983). As both works suggest in their titles, the doctrines of pendent and ancillary jurisdiction often marched under the supplemental banner 
States has attracted an enormous body of scholarly commentary, much of it critical of Congress's handiwork. ${ }^{3}$ With this body of critical commentary have come the predictable calls for reform and revision. ${ }^{4}$ Although defenders of the statute initially argued that the federal courts could work around the problems through flexible interpretation, ${ }^{5}$ the prospects for such creative solutions have diminished in re-

before they were codified in such terms in section 1367.

${ }^{3}$ Professor Richard Freer was among the first and sharpest critics of the statute. See Richard D. Freer, Compounding Confusion and Hampering Diversily: Life after Finley and the Supplemental Jurisdiction Statute, 40 EMORY L.J. 445, 471 (1991) [hereinafter Freer, Life After Finley] (attacking the supplemental jurisdiction statute for "maiming efficient packaging of diversity cases ... precluding supplemental jurisdiction in alienage cases and confusing areas that had been relatively clear"). Professor Freer's critique drew a defense from the drafters-Tom Rowe, Steve Burbank, and Tom Mengler-and the exchange grew increasingly heated. See Thomas D. Rowe, Jr. et al., Compounding Confusion or Creating Confusion About Supplemental Jurisdiction? A Reply to Professor Freer, 40 EMORY L.J. 943, 943-44 (1991) [hereinafter Rowe et al., A Reply] ("Professor Richard Freer purports to separate the wheat from the chaff and then proceeds to torch the farm, exuberantly and extensively telling the federal courts how to get it all wrong."); Thomas C. Arthur \& Richard D. Freer, Grasping at Burmt Straws: The Disaster of the Supplemental Jurisdiction Statute, 40 EMORY L.J. 963, 963 (1991) [hereinafter Arthur \& Freer, The Disaster] ("If Professor Freer in fact torched the entire farm, it is because there was so much dry straw lying around after the three drafters finished tilting with the strawmen they created in their response to Professor Freer's article."); Thomas D. Rowe, Jr. et al, $A$ Coda on Supplemental Jurisdiction, 40 EMORY L.J. 993, 1006 (1991) [hereinafter Rowe et al., $A$ Coda] (" $[W]$ e trust that cooler heads than those of Professors Arthur and Freer will join us in resisting their call to gut or scrap a needed statute that is already proving its value."); Thomas C. Arthur \& Richard D. Freer, Close Enough for Government Work: What Happens When Congress Doesn't Do Its Job, 40 EMORY L.J. 1007, 1007 (1991) [hereinafter Arthur \& Freer, Close Enough] ("[I]f only someone had spent as much time writing the statute as the trio [of drafters] has spent writing about the statute."). This more pointed rhetoric may have persuaded other scholars to steer clear of the controversy, at least initially. Some of the contributors to an Emory Symposium on the subject one year later appear to have worried about becoming entangled in a similar exchange. See Erwin Chemerinsky, Rationalizing Jurisdiction, 41 EMORY L.J. 3, 4 (1992) (describing both the drafting Trio and the critical Duo as right in certain respects and studiously declining to offer any opinion on "each point in the ... debate"); Rochelle Cooper Dreyfuss, The Debate Over \$ 1367: Defining the Power to Define Federal Judicial Power, 41 EMORY L.J. 13, 13 (1992) (noting the "intensity" of the debate but describing it as a mistake to "join issue").

1 Professors Freer and Arthur initially called for statutory revision as part of their criticism of section 1367. See Arthur \& Freer, The Disaster, supra note 3, at 985 (describing a congressional fix as the only sensible course). Since then, calls for revision have occurred with great regularity. See Christopher M. Fairman, Abdication to Academia: The Case of the Supplemental Jurisdiction Statute, 19 SETON HALL LEGIS. J. 157, 190 (1994) (calling for Congress to undertake "immediate minor revisions, major deliberative actions and a revised disclaimer"); infra note 8 (listing proposed revisions). For an account of the current reform efforts of the American Law Institute, see infra notes 69-74 and the accompanying text.

${ }^{5}$ See, e.g., Rowe et al., A Reply, supra note 3, at 960 n.90 (arguing that the reference in the legislative history might help to overcome the possibility that the statute had al- 
cent years as the federal courts have adopted a more text-centered approach to statutory interpretation. ${ }^{6}$ This rigorous textualism now threatens to reshape the rules of federal jurisdiction quite dramatically and to produce results that appear very much at odds with the relatively modest expectations of the enacting Congress."

As a consequence, a growing consensus of academic opinion now holds that Congress should revise the law of supplemental jurisdiction. One recent symposium featured articles from a variety of respected scholars, many of whom agree that section 1367 requires at least a tune-up if not a more substantial legislative overhaul. ${ }^{8}$ This

tered the rule of Zahn v. International Paper Co.); id. at 960 (suggesting that sympathetic interpretation of the statute might solve many of the problems identified by the critics); cf. Arthur \& Freer, The Disaster, supra note 3, at 983 (suggesting that the call for "sympathetic" interpretation will not overcome statutory ambiguity). For more on the problem of Zahn, see infra notes 48-54.

${ }^{6}$ Recent years have witnessed a resurgence of interest in the theory of statutory interpretation. A generation ago, courts made routine use of the legislative history of federal statutes, taking for granted the idea (now associated with the Legal Process school) that statutes respond purposively to some mischief that Congress has identified. Such purposive interpretation has faced two primary challenges: one from the public choice theorists and a second from those who emphasize the centrality of the text in the interpretive process. For an overview, see William N. Eskridge, Jr. \& Philip P. Frickey, An Historical and Critical Introduclion to The Legal Process, in HENRY M. HART, JR. \& ALBERT M. SACKS, The Legal Process li (William N. Eskridge, Jr. \& Philip P. Frickey eds., 1994). On the rise of textualism generally, and its influence on both academics and federal judges, see William N. Eskridge, Jr., Texlualism, The Unknown Ideal?, $96 \mathrm{MrCH}$. L. REv. 1509, 1511-14 (1998) (book review) (identifying Justice Antonin Scalia as the Court's leading textualist in the course of reviewing his essay on interpretation).

Justice Scalia placed his interpretive stamp on the law of supplemental jurisdiction in his opinion for the Court in Finley v. United States, 490 U.S. 545, 552 (1989), emphasizing the absence of any textual basis for the assertion of pendent-party jurisdiction. Although Congress adopted section 1367 in response, the subsequent interpretation of the statute owes much to the literal textualism that Justice Scalia insisted upon in Finley. See infra text accompanying notes $36-42$ (describing the Finley opinion authored by Justice Scalia).

${ }^{7}$ Most of this disputation has centered on the application of the new statute to actions within the diversity jurisdiction of the federal district courts. See Stromberg Metal Works, Inc. v. Press Mech., Inc., 77 F.3d 928, 931 (7th Cir. 1996) (holding that section 1367 also changes amount-in-controversy rules in ordinary multi-party diversity litigation); In re Abbott Labs., Inc., 51 F.3d 524, 529 (5th Cir. 1995) (holding that section 1367 relaxes strict rules governing amount-in-controversy determinations in diverseparty class action litigation). For a more detailed account of Abbott Laboratories and Stromberg, see infra text accompanying notes 50-59. See generally Freer, Life After Finley, supra note 3, at 475-76 (objecting to the statute's restrictive approach to diversity jurisdiction).

${ }^{8}$ All four of the lead authors in the symposium support statutory change. See Richard D. Freer, Toward a Principled Statutory Approach to Supplemental Jurisdiction in Diversity of Citizenship Cases, 74 IND. L.J. 5, 17 (1998) (arguing for statutory revision to broaden supplemental jurisdiction in diversity proceedings); John B. Oakley, Integrat- 
movement for a statutory fix coincides with last year's action of the American Law Institute ("ALI"). Acting at its meeting in May 1998, the ALI approved Tentative Draft No. 2 of a fully revised version of section 1367. ${ }^{9}$ The ALI Draft presents a new conceptual approach to the issues of supplemental jurisdiction and traces the implications of its new approach in illuminating and sometimes exhausting detail. Approval of the draft lends the ALI's prestige as an agency of law reform to the movement for a statutory revision.

Although amendments to the statute may indeed prove necessary, their adoption should await the judicial consideration of an alternative approach to the interpretation of section 1367. The alternative presented in this Article, which I refer to as "sympathetic textualism," represents an attempt to fuse two competing approaches to the interpretation of jurisdictional law, those of the legislative historians and of the rigorous textualists. In the wake of section 1367's adoption, opinion about the workability of the statute divided into two camps. On

ing Supplemental Jurisdiction and Diversity Jurisdiction: A Progress Report on the Work of the American Law Institute, 74 IND. L.J. 25, 45-52 (1998) (setting forth views of the reporter to the ALI Judicial Code Revision Project on its proposals for statutory change); Thomas D. Rowe, Jr., Section 1367 and All That: Recodifying Federal Supplemental Jurisdiction, 74 IND. L.J. 53, $70-73$ (1998) (proposing a revision of section 1367(b) that would modify the statute's operation in diversity); Joan Steinman, Crosscurrents: Supplemental Jurisdiction, Removal, and the ALI Revision Project, 74 IND. L.J. 75, 11422 (1998) (suggesting an amendment to address the problem of supplemental jurisdiction in removed cases). A good many other participants in the Indiana symposium express support for amendments as well. See, e.g., Howard P. Fink, Supplemental Jurisdiction-Take It to the Limit, 74 IND. L.J. 161, 161 (1998) (supporting an abolition of all limits on supplemental jurisdiction in diversity matters); Graham C. Lilly, Making Sense of Nonsense: Reforming Supplemental Jurisdiction, 74 IND. L.J. 181, 189-94 (1998) (proposing an abolition of complete diversity, a relaxation of the restrictions on supplemental jurisdiction, and the use of amount-in-controversy rules to limit docket pressure). On the other hand, at least some observers support a move away from more detailed rules and back to a regime of judicial discretion. See Edward H. Cooper, An Alternative and Discretionary $\S$ 1367, 74 IND. L.J. 153, 153-54 (1998) (urging the adoption of an amendment that would restore a measure of judicial discretion in the interpretation of supplemental jurisdiction); David L. Shapiro, Supplemental Jurisdiction: A Confession, An Avoidance, and a Proposal, 74 IND. L.J. 211, 218-20 (1998) (same). Like these commentators, I doubt the efficacy of greater statutory detail and support a restoration of the lawmaking partnership between Congress and the courts.

${ }^{9}$ The American Law Institute published Tentative Draft No. 1 of its Federal Judicial Code Revision Project in April 1997. Although Draft No. 1 was returned for further drafting, the Institute approved the supplemental jurisdiction proposals contained in Tentative Draft No. 2 at its meeting in May 1998. See Civil ProcedureSupplemental Jurisdiction: ALI Advocates Proposed Amendment to Supplemental Jurisdiction Statute, 66 U.S.L.W. 2719 ( May 26, 1998) (reporting the ALI's unanimous approval). For the details of the ALI proposal, see AMERICAN LAW INSTITUTE, FEDERAL JUDICIAL CODE REvision PROJECT, TENTATIVE DRAFT No. 2 (1998) [hereinafter ALI DRAFT]. 
one side were the drafters of the statute and its defenders, who argued that the federal courts could resolve textual problems with the statute through reliance upon legislative history. In contrast to those who invoked legislative history, the statute's critics insisted upon the interpretive primacy of the text and argued that the statute might well unsettle jurisdictional law. The debate between the historians and the textualists over the meaning of the supplemental jurisdiction statute corresponded to a similar debate in legisprudential circles over the role of legislative history in statutory interpretation. Indeed, it was the Court's leading textualist, Justice Antonin Scalia, who emphasized the centrality of the text in Finley $v$. United States, ${ }^{10}$ the jurisdictional decision that led to the adoption of section 1367.

In calling for a sympathetic textualism, I propose a reading of section 1367 that attempts to bridge the gap between these two schools of interpretive thought. My sympathetic approach takes the expressed purpose of Congress and the history of pendent and ancillary jurisdiction as valid (if not controlling) considerations and uncovers new interpretive possibilities in the language of the statute. I thus follow to some extent the lead of the more historically minded drafters of the statute, who first called for a "sympathetic" consideration of legislative purpose in the interpretation of the statute." The textualism I advance here may also appeal to the more rigorous textual critics of the statute. For even the most committed textualist will often invoke canons of statutory construction to aid the interpretive process, as Justice Scalia's own textualist decision in Finley reveals. Finley invoked the canon that Congress, in revising and consolidating the laws, does not intend to change their effect unless such intention is "clearly expressed."m12 Such a rule establishes a regime of continuity with the past, very much in keeping with the insights in Professor David Shapiro's thoughtful defense of the use of the canons in the interpretive process. ${ }^{13}$ The canons can thus assist the textualist, as Professor Shapiro notes, in a "sincere and sympathetic effort" to uncover the meaning of a statute by reminding us all that statutes rarely produce unan-

${ }^{10} 490$ U.S. 545,552 (1989).

"See supra note 5 (noting the drafters' preference for a sympathetic interpretation for the statute).

${ }^{12}$ Finley, 490 U.S. at 554 (quoting Anderson v. Pacific Coast S.S. Co., 225 U.S. 187, 199 (1912)).

${ }^{13}$ See David L. Shapiro, Continuily and Change in Statutory Interpretation, 67 N.Y.U. L. REV. 921, 925 (1992) (arguing that "the dominant theme running through most interpretive [canons] that actually influence outcomes is that close questions of construction should be resolved in favor of continuity and against change"). 
nounced but revolutionary changes in the law. ${ }^{14}$

My sympathetic textualism produces a reading of section 1367 that fits well both with the legislative history's expressed desire to preserve the established rules of complete diversity and with the canonical emphasis on continuity with the past. In particular, my approach reads section 1367 (a) as having incorporated the joinder and aggregation rules of complete diversity into its requirement that the district courts first obtain "original jurisdiction" of the claims in a civil action. On this account, the grant of supplemental jurisdiction in section 1367(a) does not supplant diversity's joinder and aggregation rules but comes into play in diversity proceedings only after those requirements have been satisfied. Similarly, the restrictions in section 1367(b) operate to prevent the erosion of the complete diversity requirement that might otherwise result from an expansive application of what was once termed the doctrine of ancillary jurisdiction. So read, the statute leaves in place differences that had marked the pre-codification operation of the doctrine of supplemental jurisdiction in federalquestion and diversity matters, and occasions none of the unexpected changes in law that the current interpretive approach ascribes to the statute. In thus proposing a reading of section 1367 that corresponds to Congress's apparent design, this Article's "sympathetic textualism" may obviate the need for further legislative tinkering and restore the courts' role in the further elaboration of supplemental jurisdictional law.

The Article develops its case for a sympathetic interpretation of section 1367 in three parts. Part I reviews the origins of the supplemental jurisdiction statute and sketches its academic and judicial reception. I show that, beneath the surface of an ongoing debate over its proper interpretation, a broad consensus has developed concerning the meaning of the statutory text. Part II of the Article presents a more sympathetic alternative to the standard account of the text. Building on the important jurisdictional distinction between federalquestion cases and diverse-party controversies, and the way that distinction informed the evolution of the judge-made doctrines of pendent and ancillary jurisdiction that became supplemental jurisdiction, the Article proposes and defends an interpretation of section 1367(a) that leaves the federal courts free to apply the tenets of diversity jurisdiction as they continued to evolve before and after the statute's adoption. Part III suggests that the Article's contrast between sympathetic

${ }^{14}$ Id. at 926. 
and unsympathetic textualism may shed some light on current debates over the proper role of the federal courts in the interpretation of jurisdictional statutes and on the need for further reform of the kind now contemplated in the work of the ALI.

\section{THE STANDARD ACCOUNT OF SECTION 1367}

Although fierce academic battles have marked much of the field of supplemental jurisdiction, ${ }^{15}$ some uncontested terrain remains. Perhaps most importantly, one finds in the literature a virtually universal and largely unspoken consensus about the best way to understand the interplay between the first two subsections of section $1367 .^{16}$ The Article describes this reading as the standard account of section

${ }^{15}$ See supra note 3 for its collection of citations giving an overview of the battleground. One author assessed the casualties by ascribing to his mother the comment that a "lot of fur" was flying. Rowe, supra note 8, at 53.

${ }^{16}$ One finds the assumption that the broad grant of supplemental jurisdiction in section 1367(a) operates with the same impact in both federal-question and diversity matters in virtually every published writing on the subject. See ALI DRAFT, supra note 9 , at 58, 76 (showing that the reference to Rule 20 occasions a decisive narrowing of an otherwise broad grant of supplemental jurisdiction by indicating that section 1367(a) would have had a "revolutionary" effect on diversity litigation but for the restrictions in subsection (b), and that the "plain meaning" of section 1367 trumps the aggregation rules in diversity only where the plaintiffs sue a single defendant); Arthur \& Freer, The Disaster, supra note 3, at 982 (indicating that the grant of jurisdiction in subsection (a) "over all claims satisfying the constitutional test for supplemental jurisdiction" may overrule Strawbridge); Freer, Life After Finley, supra note 3, at 485 (noting that section 1367(a) extends supplemental jurisdiction to the constitutional limit while section 1367(b) creates exceptions; recognizing the omission of the exception for Rule 23; and so assuming full pendent-party jurisdiction was conferred in subsection (a)); Wendy Collins Purdue, The New Supplemental Jurisdiction Statute-Flawed But Fixable, 41 EMORY L.J. 69, 77 (1992) (indicating that section 1367(b) fails to answer the question of jurisdiction presented by class action joinder under Rule 23 or by nondiverse plaintiff joinder under Rule 20 and thus revealing an assumption that subsection (a) authorizes supplemental jurisdiction of such matters in diversity); Rowe et al., $A$ Reply, supra note 3, at 960-61 nn.90-91 (acknowledging that section 1367 might overrule Zahn and Strawbridge and thus interpreting section 1367(a) as a broad grant of pendent jurisdiction applicable to diversity matters); Joan Steinman, Section 1367-Another Party Heard From, 41 EMORY L.J. 85, 95-96 (1992) (indicating that, in diversity matters and in the absence of an exception in subsection (b), the grant of supplemental jurisdiction in subsection (a) requires not an inquiry into consistency with section 1332 but an inquiry into transactional relationship under Article III); see also Lilly, supra note 8, at 184 (describing the broad grant of supplemental jurisdiction in section 1367 (a) as operating without regard to the jurisdictional basis on which plaintiff grounds the action); Stephen C. Yeazell, Teaching Supplemental Jurisdiction, 74 IND. L.J. 241, 246 (1998) (describing the broad grant of supplemental jurisdiction in section 1367(a) as partially retracted as to diversity matters in subsection (b)). 
1367. To understand the standard account and to see how it influences modern interpretations of the statute requires some background on the nature of supplemental jurisdiction. After providing the necessary background, this Part sets out the standard account of section 1367, notes its influence with courts and commentators, and shows how it informs the revision project of the ALI.

\section{A. The Origins of Supplemental Jurisdiction}

Section 1367 represents an attempt by Congress to codify the doctrines of pendent and ancillary jurisdiction under the common rubric of supplemental jurisdiction. ${ }^{17}$ The Supreme Court had developed the two doctrines in a series of decisions running well back into the nineteenth century ${ }^{18}$ without much in the way of explicit guidance from Congress ${ }^{19}$ and without identifying an entirely satisfying conceptual or statutory basis for them..$^{20}$ As a consequence, the judicial doc-

${ }^{17}$ See McLaughlin, supra note 1 , at 860 (expressing approval of Congress's "beneficial" decision to abandon the old labels of pendent and ancillary jurisdiction in favor of the generic term "supplemental jurisdiction").

${ }^{18}$ Ancillary jurisdiction developed first, as the Supreme Court agreed to permit the assertion of jurisdiction over claims brought by intervenors who sought to perfect claims to property other litigants had previously brought within the custody of a federal court. See, e.g., Freeman v. Howe, 65 U.S. (24 How.) 450, 460 (1860) (upholding jurisdiction over "ancillary and dependent [claims] ... without reference to the citizenship or residence of the parties"). The Court extended ancillary jurisdiction in a series of subsequent cases. See Moore v. New York Cotton Exch., 270 U.S. 593 (1926) (upholding ancillary jurisdiction over defendant's compulsory counterclaim under state law). See generally Freer, supra note 2, at 50-53 (arguing that the development of ancillary jurisdiction served the twin goals of allowing efficient packaging of cases and avoiding duplicative litigation).

Pendent jurisdiction developed along a separate track, as plaintiffs in federalquestion cases came to join state-law claims as part of their "cause of action" against the defendant. See Hurn v. Oursler, 289 U.S. 238, 247 (1933) (describing federal copyright claim and state unfair competition claims as two grounds in support of the "same cause of action"); Siler v. Louisville \& Nashville R.R., 213 U.S. 175, 192-93 (1909) (holding that jurisdiction over federal due process claim encompassed related state-law claim challenging rates as having exceeded state authority); McLaughlin, supra note 1, at 870-71 (describing how pendent-claim jurisdiction developed separately from ancillary jurisdiction).

19 See JACK H. FRIEDENTHAL ET AL., CTVIL PROCEDURE § 2.12-.14 (1985) (describing pendent and ancillary jurisdiction as judicially created); CFARLES ALAN WRIGHT, THE LAW OF FEDERAL COURTS 103-06 (5th ed. 1994) (describing the judicial origin of pendent and ancillary jurisdiction doctrines); cf. Freer, supra note 2, at 55 (noting the "oxymoron[ic]" tradition of regarding supplemental jurisdiction as a "common law" doctrine of "subject matter jurisdiction" and arguing that such doctrines should be seen as interpretations of the statutory grant of jurisdiction over a civil action).

${ }^{20}$ On the lack of an adequate statutory foundation, see Freer, supra note 2, at 55. 
trine of supplemental jurisdiction showed some of the messy signs of case-by-case elaboration, with curious stops and starts along the way. Although the Court adopted a rather expansive approach to pendent jurisdiction in the federal-question context of United Mine Workers $v$. Gibbs, ${ }^{21}$ its more cautious approach in Owen Equipment $\mathcal{E}^{2}$ Erection Co. v. Kroger sought to prevent ancillary jurisdiction from eroding the rule of complete diversity. ${ }^{22}$

The contrast between Gibbs and Kroger provides a useful introduction to the conceptual underpinnings of supplemental jurisdiction and to the debate that continues to swirl around the statute. In Gibbs, the plaintiff brought suit in federal court alleging both a secondaryboycott claim under federal labor law and a state-law claim for interference with advantageous business relations. ${ }^{23}$ In the current parlance of supplemental jurisdiction, we would refer to the federalquestion claim as "jurisdictionally sufficient," "jurisdiction conferring," or, in the words of the ALI Draft, "freestanding," to convey the notion that the claim supports an assertion of original jurisdiction on its own and without regard to any other claim in the action. ${ }^{24}$ By way of contrast, the state-law claim lacked this jurisdictional sufficiency or freestanding quality in light of the absence of complete diversity between the plaintiff and defendants. Nonetheless, the Gibbs Court agreed that the district courts may assert what was then known as pendent-claim jurisdiction over the state-law claim. The Court reasoned that the state-law claim arose from the "same common nucleus of operative fact" as the freestanding claim and the two claims thus formed

${ }^{21} 383$ U.S. 715, 721-29 (1966) (holding that pendent jurisdiction exists over statelaw claims which constitute part of the same constitutional "case" as one or more federal-question claims).

${ }^{22} 437$ U.S. $365,373-77$ (1978) (citing the complete-diversity rule in refusing to permit plaintiff to join a claim against a nondiverse, impleaded third-party defendant).

${ }^{23}$ See Gibbs, 383 U.S. at 718-20 (describing the plaintiff's suit and the circumstances giving rise to it).

${ }^{24}$ Courts and commentators have struggled somewhat in their search for the best shorthand expression to capture the concept of a claim that falls within the district court's original jurisdiction and might provide a jurisdictional anchor for the assertion of supplemental jurisdiction. See Kroger, 437 U.S. at 372 n.11 (distinguishing between "federal" and "nonfederal" claims); Palmer v. Hospital Auth., 22 F.3d 1559, 1566 (11th Cir. 1994) (distinguishing between "anchor[]" claims and "supplemental" claims); $c f$. McLaughlin, supra note 1, at 869 (distinguishing the "jurisdiction ... supporting" federal-question claim in Gibbs from the "jurisdictionally insufficient" state-law claim). I agree with the ALI drafters that the term "freestanding" captures the idea of jurisdictional sufficiency as well as any. See ALI DRAFT, supra note 9, at 35-43 (defining and illustrating the difference between "freestanding" and "supplemental" claims). 
a single constitutional case for purposes of Article III. ${ }^{25}$ The Court also noted that a decision to permit the district courts to hear the claims would serve the interests of litigant convenience and judicial economy and help to secure the just and speedy resolution of disputes. $^{26}$

Although similar concerns with litigant fairness and judicial economy underlay the development of ancillary jurisdiction, the Court's decision in Kroger revealed a competing concern for the completediversity rule. ${ }^{27}$ In Kroger, the plaintiff brought suit against a single diverse defendant, asserting a state-law claim for personal injuries that satisfied the amount-in-controversy requirement. ${ }^{28}$ (The ALI Draft would treat such a claim as "freestanding. ${ }^{29}$ ) The defendant impleaded a third-party defendant in accordance with Rule 14 of the Federal Rules of Civil Procedure, arguing that the new defendant might bear responsibility for some portion of any award to the plaintiff. $^{30}$ The plaintiff responded by asserting claims against this new defendant, as Rule 14 further contemplates. ${ }^{31}$ Both supplemental claims-that by the defendant and that by the plaintiff-satisfied the "common nucleus" test of Gibbs and a decision to permit jurisdiction

${ }^{25}$ The Gibbs Court acknowledged that the two claims might not satisfy the test of Hurn v. Oursler, 270 U.S. 593 (1926), as two grounds in support of the same "cause of action" but dismissed the Hum test as "unnecessarily grudging." Gibbs, 383 U.S. at 725. Instead, the Court held that the district courts may assert pendent-claim jurisdiction over a state-law claim that arises from the same "common nucleus of operative fact" as the federal-question claims. Id. This "common nucleus" test has been quite widely regarded as allowing the exercise of jurisdiction over claims that satisfy many of the transactional tests set forth in the Federal Rules of Civil Procedure and as extending the scope of jurisdiction to the boundaries of Article III of the Constitution. Cf. infra note 45 (describing the contention that Article III permits district courts to hear set-off claims that do not satisfy the common-nucleus test).

${ }^{26} \mathrm{See} i d$. at 726 (noting that the justification for pendent jurisdiction "lies in considerations of judicial economy, convenience and fairness to litigants").

${ }^{27}$ See Kroger, 437 U.S. at 374 (noting that under a sufficiently expansive theory of supplemental jurisdiction, "a plaintiff could defeat the statutory requirement of complete diversity by the simple expedient of suing only those defendants who were of diverse citizenship and waiting for them to implead nondiverse defendants").

${ }^{28}$ Id. at 367.

29 See ALI DRAFT, supra note 9, at 36-37 (noting that its definition of a "freestanding" claim encompasses claims within the original jurisdiction of the district courts on the basis of both the federal-question and diversity jurisdictional grants).

${ }^{30}$ See FED. R. CIV. P. 14(a) (providing for the defendant to implead a third-party defendant on a claim that such defendant "is or may be liable" for some portion of the plaintiff's claim against the original defendant).

${ }^{31}$ See id. (providing that the plaintiff may assert any claim against the third-party defendant arising out of the same transaction or occurrence that is the subject matter of the plaintiff's claim against the original defendant). 
over the entire "case" would have served the interests of convenience and economy. But the Kroger Court refused to go so far, emphasizing the availability of state court as a convenient, alternative forum. While the Court expressed a willingness to permit the assertion of jurisdiction over the defendant's ancillary claims against a new party under Rule $14,^{32}$ it refused to extend such jurisdiction to the claims of the plaintiff against the new party. ${ }^{33}$ The Court worried that plaintiffs might omit nondiverse defendants from their initial complaint, await their predictable impleader under Rule 14, and then amend their complaint to assert the previously omitted claims, a strategy that might undermine the complete-diversity requirement. ${ }^{34}$

Although the restrictive approach of Kroger attracted some negative reviews, ${ }^{35}$ it was the Court's decision in Finley $v$. United States ${ }^{36}$ that gave rise to the enactment of section 1367. The Finley plaintiff brought suit against the United States for tort damages (a "freestanding" claim under federal law) and joined state-law claims against nondiverse defendants who allegedly bore responsibility for the airplane crash that led to the litigation. ${ }^{37}$ Despite the obvious transactional relationship among the claims, the Finley Court refused to permit the assertion of what was then termed pendent-party jurisdiction over the plaintiff's state-law claims against the nondiverse defendants. ${ }^{38}$ The

${ }^{32}$ See Kroger, 437 U.S. at 375 n.18 (citing with apparent approval decisions that authorize the assertion of ancillary jurisdiction over claims by defendants against impleaded third-party defendants).

${ }^{3 s}$ See id. at 375-76 (emphasizing that the proposed assertion of ancillary jurisdiction over a claim by a plaintiff who had voluntarily chosen the federal diversity docket differed significantly from that over a claim by a defendant "haled into court against his will").

${ }^{34}$ See id. at 377 ("To allow the requirement of complete diversity to be circumvented as it was in this case would simply flout the congressional command.").

${ }^{35}$ See Freer, Life After Finley, supra note 3, at 459-61 (arguing that Kroger was wrongly decided); McLaughlin, supra note 1, at 880 (arguing that Kroger failed to define the "permissible limits of supplemental jurisdiction").

${ }^{56} 490$ U.S. 545 (1989). All of the scholarly and judicial commentary on the statute recognizes the decisive role that Finley played in leading Congress to adopt section 1367. See, e.g., CHARLES ALAN WRIGHT ET AL., 13 FEDERAL PRACTICE AND PROCEDURE: JURISDICTION AND RELATED MATTERS 2d, § 3523, at 65 (Supp. 1999) [hereinafter FEDERAL PRACTICE] (ascribing the origins of section 1367 to the decision in Finley); McLaughlin, supra note 1, at 889 (same).

${ }^{37}$ See Finley, 490 U.S. at 546 (noting that plaintiff sued the United States under the Federal Tort Claims Act ("FTCA") and then "moved to amend the federal complaint to include claims against the original state-court defendants, as to which no independent basis for federal jurisdiction existed").

"See id. at 553, 556 (stating that "[t] he statute here defines jurisdiction in a manner that does not reach defendants other than the United States" and declining to 
Finley Court acknowledged the strength of the arguments of litigant convenience and judicial economy, arguments made stronger by the plaintiff's inability as in Kroger to join claims against all the defendants in a single state court proceeding. ${ }^{39}$ But the Court nonetheless refused to approve jurisdiction over the pendent parties, citing the absence of any written statutory authorization for such jurisdiction. ${ }^{40} \mathrm{Al}-$ though the Court distinguished Gibbs and the situation of pendentclaim jurisdiction, ${ }^{41}$ its emphasis on the absence of a statute appeared to threaten many established forms of supplemental jurisdiction over additional parties. ${ }^{42}$

permit the assertion of pendent-party jurisdiction).

${ }^{39}$ See $i d$. at 555 (acknowledging that its decision would sacrifice the efficiency and convenience of litigating multiple claims in a single action); cf. id. at 555-56 (refusing to adopt dicta in Aldinger v. Howard, 427 U.S. 1, 18 (1976), which had hinted that the exclusive jurisdiction conferred in the FTCA over claims against the United States provided a strong argument for the exercise of pendent-party jurisdiction).

${ }^{40}$ See id. at 552 (emphasizing that the jurisdictional grant in question spoke of "civil actions on claims ... against the United States" and did not, by its terms, authorize claims against anyone else).

"See id. at 549-51 (emphasizing the fundamental analytical difference between the pendent-claim jurisdiction in Gibbs and the joinder of parties not named in any claim that is independently cognizable); id. at 556 (describing Gibbs as "a departure from prior practice" that the Court had no intent to "limit or impair").

42 See Thomas M. Mengler, The Demise of Pendent and Ancillary Jurisdiction, $1990 \mathrm{BYU}$ L. REV. 247, 258-60 (arguing that the rationale of Finley threatened ancillary jurisdiction as well as the pendent-claim jurisdiction recognized in Gibbs); $c f$. McLaughlin, supra note 1, at 887-89 (noting that Finley threatened Gibbs by characterizing the decision as a departure from prior practice and summarizing post-Finley judicial decisions).

Apart from the threat, Finley also issued an invitation to Congress. By emphasizing the need for jurisdiction conferred by "written law," Finley, 490 U.S. at 547 (quoting Ex parte Bollman, 8 U.S. (4 Cranch) 75, 93 (1807)), the Court obviously contemplated the possibility that Congress might supply the law in question. The Court also supplied a set of "interpretive rules" to enable Congress to "know the effect of the language it adopts." Finley, 490 U.S. at 556. The rules appeared earlier in the opinion, in the course of its rejection of the argument that existing statutory provisions conferred jurisdiction in terms flexible enough to support an exercise of pendent jurisdiction. This argument for flexible interpretation rested upon the recodification of the jurisdictional statutes in 1948 against the backdrop of decisions that had expanded the scope of jurisdiction over civil actions to take account of the growth in the litigation unit reflected in the Federal Rules. But the Finley Court rejected this flexible approach, noting that the real growth in pendent jurisdiction came in Gibbs-a decision that came down well after the 1948 recodification had occurred. See id at 555 (noting that the liberalization of pendent-party jurisdiction effected by Gibbs occurred "nearly 20 years later" than the recodification the plaintiff relied on). 


\section{B. The Text and Meaning of Section 1367}

Congress responded with section $1367 .^{43}$ As commonly interpreted, the statute confers a broad grant of supplemental jurisdiction in subsection (a), allowing the district courts to hear nonfederal claims that bear an appropriately close relationship to the claims over which the court has original jurisdiction. ${ }^{44}$ The statute follows Gibbs in defining the scope of supplemental jurisdiction and expressly permits the assertion of jurisdiction over pendent parties, thus supplying the

43 Section 1367 reads as follows:

(a) Except as provided in subsections (b) and (c) or as expressly provided otherwise by Federal statute, in any civil action of which the district courts have original jurisdiction, the district courts shall have supplemental jurisdiction over all other claims that are so related to claims in the action within such original jurisdiction that they form part of the same case or controversy under Article III of the United States Constitution. Such supplemental jurisdiction shall include claims that involve the joinder or intervention of additional parties.

(b) In any civil action of which the district courts have original jurisdiction founded solely on section 1332 of this title, the district courts shall not have supplemental jurisdiction under subsection (a) over claims by plaintiffs against persons made parties under Rule 14, 19, 20, or 24 of the Federal Rules of Civil Procedure, or over claims by persons proposed to be joined as plaintiffs under Rule 19 of such rules, or seeking to intervene as plaintiffs under Rule 24 of such rules, when exercising supplemental jurisdiction over such claims would be inconsistent with the jurisdictional requirements of section 1332.

(c) The district courts may decline to exercise supplemental jurisdiction over a claim under subsection (a) if-(1) the claim raises a novel or complex issue of State law, (2) the claim substantially predominates over the claim or claims over which the district court has original jurisdiction, (3) the district court has dismissed all claims over which it has original jurisdiction, or (4) in exceptional circumstances, there are other compelling reasons for declining jurisdiction.

(d) The period of limitations for any claim asserted under subsection (a), and for any other claim in the same action that is voluntarily dismissed at the same time as or after the dismissal of the claim under subsection (a), shall be tolled while the claim is pending and for a period of 30 days after it is dismissed unless State law provides for a longer tolling period.

(e) As used in this section, the term "State" includes the District of Columbia, the Commonwealth of Puerto Rico, and any territory or possession of the United States.

${ }^{11}$ See, e.g., Lilly, supra note 8, at 184 (describing the statute as opening in subsection (a) with a "broad conferral of supplemental jurisdiction" and following that grant with limits in subsection (b) on the scope of such jurisdiction in diversity matters); Yeazell, supra note 16, at 246 (explaining that the statute "establishes a broad jurisdictional grant in subsection (a) and then retracts much of that grant in subsection (b), whose restrictions apply to diversity-only cases"). 
statutory underpinning that the Finley Court identified as missing. ${ }^{45}$ Subsection (b) seeks to preserve certain of the limitations that had developed on the exercise of supplemental jurisdiction in the diversity cases. In particular, subsection (b) codifies the rule of Kroger by foreclosing the assertion of jurisdiction over claims by plaintiffs against persons made parties under Rule $14 .^{46}$ Subsection (c) codifies the discretionary factors that the Gibbs Court had directed district courts to consider in determining whether to assert supplemental jurisdiction. ${ }^{47}$

Although section 1367 has generated an enormous body of scholarly literature and a raft of conflicting lower court decisions, the proper reading of its text has become a matter of quite widespread consensus. Both the statute's detractors and defenders agree that subsection (a) provides a broad grant of supplemental jurisdiction that applies to both federal-question and diversity proceedings and extends to the limits of Article III. Both camps agree that the exceptions to this grant of supplemental jurisdiction appear in subsection (b) and operate primarily in diversity litigation. But despite widespread agreement about the interplay between subsections (a) and (b) -what I call the standard account of section 1367-scholars and courts disagree about the legal effect of the enacted words. Critics charge that the plain meaning of the statute makes or threatens a series of sweeping changes in the law of supplemental jurisdiction; defenders cite legislative history that clearly shows a desire on the part of Congress simply to overrule Finley and codify most of the pre-Finley status quo.

${ }^{15}$ For useful discussions of the relationship between the constitutional limits of supplemental jurisdiction and the "common nucleus" test of Gibbs, see William A. Fletcher, "Common Nucleus of Operative Fact" and Defensive Set-Off: Beyond the Gibbs Test, 74 IND. L.J. 171 (1998), which argues in favor of the existence of constitutional power to adjudicate an unrelated defensive set-off, despite the absence of any common nucleus among the freestanding and supplemental claims. See also McLaughlin, supra note 1, at 890-95 (explaining the relationship between the constitutional case or controversy requirement and the supplemental jurisdiction statute).

${ }^{46}$ On the statute's preservation of the rule of Kroger, see McLaughlin, supra note 1, at 936-40. Critics of the statute admit that it preserves the rule of Kroger, and focus their criticism on the decision to do so. See, e.g., Arthur \& Freer, The Disaster, supra note 3, at 975-78 (arguing that Krogerwas wrongly decided and that the statute not only preserved but extended its wrongheaded features); Freer, supra note 8, at 13-15 (same).

${ }^{47}$ As the Supreme Court explained, subsection (c) "codifie[s] [the] principles" of economy, convenience, fairness, and comity that inform the discretionary regime of Gibbs. City of Chicago v. International College of Surgeons, 522 U.S. 156, 165 (1997). For doubts about the effectiveness of the codification, see ALI DRAFr, supra note 9 , at 78-95 (arguing that the statute may have invited lower federal courts to refrain from hearing claims, such as "freestanding" and ancillary claims, to which the regime of discretion should not apply). 
One can best understand this familiar debate over the proper roles of text and legislative history in statutory interpretation by considering the impact of section 1367 on the amount-in-controversy rule of Zahn v. International Paper Co. ${ }^{48}$ The Zahn Court held that, even where the claims of the named plaintiffs meet the threshold amount, diversity jurisdiction does not extend to those unnamed members of a plaintiff class whose individual claims fail to meet the amount-incontroversy requirement. ${ }^{49}$ The standard account of the statute holds that the plain meaning of section 1367 alters the outcome in Zahn. After jurisdiction attaches to the jurisdictionally sufficient claim of a single, named class representative (a "freestanding" claim), section 1367(a) provides supplemental jurisdiction over the jurisdictionally insufficient but related claims of the additional class members. Moreover, since 1367(b) does not specify an exception for claims joined under Rule 23 (class actions), the broad grant in subsection (a) controls the outcome.

Although the argument that the text of section 1367 overrules Zahn first appeared in Professor Freer's critique of the statute, ${ }^{50}$ the Fifth Circuit has given it the force of law. Its decision in In re Abbott Laboratories, Inc. ${ }^{51}$ features the standard textual argument in the heart of its opinion: "Section 1367(a) grants district courts supplemental jurisdiction over related claims generally, and § 1367(b) carves exceptions. Significantly, class actions are not among the exceptions.,52 Having made the textual argument, the Abbott Laboratories court acknowledged that the House had included a statement in the legislative history to the effect that the section was not intended to overrule $Z a h n .^{53}$ But the court refused to look behind the text, concluding that section 1367 authorized the assertion of jurisdiction rejected in $Z a h n .{ }^{54}$

414 U.S. 291 (1973).

49 See id. at 301 (holding that the district courts, sitting in diversity, may not assert jurisdiction over the claims of unnamed class members who fail to meet the amount-incontroversy requirement).

${ }^{50}$ See Freer, Life After Finley, supra note 3, at $485-86$ (criticizing the statute as a threat to $Z a h n$ and implying that the disclaimer of this interpretation in the legislative history is an insufficient precaution); $c$. Freer, supra note 8 , at 18 (opining that "[a]ll observers agree that the supplemental-jurisdiction statute, on its face, overrules Zahn $n^{n}$ ).

5151 F.3d 524 (5th Cir. 1995).

52 Id. at 527.

${ }^{33}$ See id. at 528 (citing H.R. REP. No. 101-734, at 29 (1990), reprinted in 1990 U.S.C.C.A.N. 6860,6875 n.17, which, the court states, "cites Zahn as a pre-Finley case untouched by the Act").

${ }^{54}$ See id. at 528-29 (stating that "[w]e are persuaded that under $\$ 1367$ a district court can exercise supplemental jurisdiction over members of a class, although they 
The Fifth Circuit expressly refused to enter into a discussion of the "wisdom of Zahn"; that was "not our affair.",55

With the growing emphasis on textualism, and the accompanying distrust of legislative history, the widespread acceptance of the standard account of section 1367 appears likely to threaten a number of established jurisdictional rules. In Stromberg Metal Works, Inc. v. Press Mechanical, Inc. ${ }^{56}$ the Seventh Circuit followed the lead of the Fifth in holding that section 1367 overrules the jurisdictional rule of Clark $v$. Paul Gray, Inc. ${ }^{57}$ The Clark court held that diversity jurisdiction attaches only to the claims of plaintiffs, joined under Rule 20, whose individual claims meet the amount-in-controversy threshold. ${ }^{58}$ The Stromberg court concluded that section 1367 altered that result by conferring a supplemental jurisdiction on the district courts broad enough to encompass the related, but jurisdictionally insufficient, claims of additional plaintiffs. ${ }^{59}$

Much the same textualism informs the Fourth Circuit's decision that section 1367 overturns the legal-certainty rule of St. Paul Mercury Indemnity Co. v. Red Cab Co. ${ }^{60}$ The St. Paul court held that diversity jurisdiction attaches at the threshold to claims that the plaintiff asserts in the complaint, unless it appears to a legal certainty that the claims will not satisfy the jurisdictional amount. ${ }^{61}$ In Shanaghan $v$. Cahill, $^{62}$ the Fourth Circuit read section 1367 as supplanting the St. Paul rule. In particular, the Fourth Circuit concluded that the summary disposition of one of three aggregated claims-a disposition that brought the amount claimed below the jurisdictional amount-brought into play the discretionary power of the district court to decline jurisdiction over the remaining claims. ${ }^{63}$ The Fourth Circuit acknowledged that

did not meet the amount-in-controversy requirement. ...").

${ }^{35}$ Id. at 529.

5677 F.3d 928 (7th Cir. 1996).

${ }^{57}$ See Stromberg Metal Works, Inc. v. Press Mech., Inc., 77 F.3d 928, 930-31 (7th Cir. 1996) (concluding that section 1367 overrules Clark v. Paul Gray, Inc., 306 U.S. 583 (1939)).

${ }^{58} \mathrm{See}$ Clark, 306 U.S. at $\mathbf{5 8 9}$ (holding that a claim asserted in a diversity case must separately meet the amount-in-controversy requirement).

${ }^{59}$ See Stromberg Metal Works, Inc., 77 F.3d at 931.

${ }^{60} 303$ U.S. 283 (1938).

${ }^{61}$ See id, at 288.

62 58 F.3d 106 (4th Cir. 1995).

bs See id. at 112 (holding that "[i]f some event subsequent to the complaint reduces the amount in controversy, such as the dismissal of one count...., the court must then decide in its discretion whether to retain jurisdiction over the remainder of the case"). See also Stevenson v. Severs, 158 F.3d 1332, 1334 (D.C. Cir. 1998) (holding that when dismissal of claims reduces the amount in controversy below the statutory minimum, 
this discretionary regime departed from the old rule, which had treated the amounts claimed in the complaint as controlling and ignored actual awards in determining whether the plaintiff satisfied the jurisdictional amount requirement. Nonetheless, the court concluded that section 1367 had effected a change in the law by making the discretionary regime of subsection (c) applicable to such aggregated claims. ${ }^{64}$

Scholars have identified a good many other settled jurisdictional rules that the statute, read in keeping with the standard account, might alter. Without elaborating all of the potentially affected areas, it seems plain that section 1367 might alter the complete-diversity rule of Strawbridge $v$. Curtiss ${ }^{65}$ and could modify in important respects the manner in which supplemental jurisdiction operates in removed cases. $^{66}$ The Court itself has already interpreted section 1367 as conferring jurisdiction on the district courts to hear pendent claims in the nature of cross-system petitions for appellate review of state administrative proceedings, a decision driven by the kind of textualism that informs the standard account. ${ }^{67}$ As a result of these and other possible changes, scholars who initially defended the statute against charges of ambiguity have now reluctantly concluded that some re-drafting may be necessary. ${ }^{68}$

"the district court has discretion to entertain the remaining claim if it so chooses," pursuant to section 1367 (c)'s discretionary dismissal provision). But see Wolde-Meskel v. Vocational Instruction Project Community Serv., Inc., 166 F.3d 59, 65 (2d Cir. 1999) (holding that " $[w]$ hen state law claims are aggregated, regardless of the amounts at issue, all of them together are 'original,' and none of the constituent claims are 'supplemental,'" making section 1367 (c)'s discretionary-dismissal regime inapplicable).

${ }^{6}$ See Shanaghan, 58 F.3d at 111 (holding that "the strict St. Paul rule is inconsistent with the statutory framework of $\S 1367$ and so must be modified to fit the contemporary congressional view of federal jurisdiction").

${ }_{65} 7$ U.S. (3 Cranch) 267 (1806). The complete-diversity rule of Strawbridge v. Curtiss holds that citizens of the same state may not appear on opposing sides of a diversity proceeding. See id. The failure of section 1367(b) to include the joinder of additional plaintiffs under Rule 20 could support a textual argument that the statute overrules Slrawbridge. See, e.g., Rowe et al., A Reply, supra note 3, at $961 \mathrm{n} .91$ ("We can only hope that the federal courts will plug that potentially gaping hole in the complete diversity requirement....").

${ }^{66}$ For a summary of the questions that scholars have raised about the application of section 1367 to actions removed to federal court, see infra notes 151-56 and accompanying text.

${ }^{67}$ See City of Chicago v. International College of Surgeons, 522 U.S. 156, 168-69 (1997) (holding that a pendent claim seeking appellate review of a local administrative decision may fall within section 1367's grant of supplemental jurisdiction).

${ }^{6 s}$ See, e.g., Rowe, supra note 8, at 53-54 (suggesting that the time has come to shift the focus of the debate regarding section 1367 from the problems with the current statute to the best way to redraft it). But cf. id. at 57-58 (worrying cogently that highly 


\section{The Proposal of the American Law Institute}

The movement for reform received a boost from the decision of the American Law Institute to approve a new and more detailed draft of section 1367 (the "ALI Draft") for possible enactment into law by Congress. According to the project's Reporter, John B. Oakley, the ALI Draft of section 1367 proposes to reconceptualize the interplay between original and supplemental jurisdiction. ${ }^{69}$ Based upon the insight that the rules now governing the joinder of claims and parties in diversity jurisdiction are themselves rules of supplemental jurisdiction, ${ }^{70}$ the ALI Draft proposes a more general approach that distinguishes between "freestanding" and "supplemental" claims." Then, with admirable rigor and attention to detail, the ALI Draft specifies a set of rules to govern the exercise of supplemental jurisdiction. In the course of the work, the ALI Draft revises and extends the criticisms that others have made of the current version of section 1367.

Although they defy easy summary, the 165 pages that comprise the ALI Draft and its accompanying commentary, memoranda, and appendices reveal much the same commitment to a rigorous textualism that has characterized the Abbott Laboratories and Stromberg decisions. ${ }^{72}$

literal textualism may undermine the creation of a sound, practical relationship between the federal courts and Congress).

${ }^{69}$ As the ALI Draft acknowledges, reconceptualization comes at a price. In a candid and, to my mind, accurate description of the likely reaction of many judges and practicing lawyers, the draft admits that readers who try to take in the complexity of the statute may feel some "indigestion." ALI DRAFT, supra note 9, at xvii.

${ }^{70}$ See id. (concluding that the rule of complete diversity is not in tension with the concept of supplemental jurisdiction but is a rule of supplemental jurisdiction that restricts its operation in diversity cases).

${ }^{7}$ According to the Draft, "freestanding" claims are those that come "within the original jurisdiction of the district courts without reliance upon supplemental jurisdiction." Id. "Supplemental" claims are not freestanding but they bear a relationship to them such that, together, they form a single case or controversy within the meaning of Gibbs. See id. at 35-39 (setting forth the text of a proposed replacement for section 1367(a) which distinguishes in a definitional section between freestanding and supplemental claims). By breaking down the jurisdictional analysis into what it calls claimspecific terms and by treating both federal-question claims and diversity claims as potentially "freestanding," the ALI Draft makes clear that it intends to extend jurisdiction on a conceptually similar basis to supplemental claims in both federal-question and diverse-party proceedings. See id. at 31-37 (laying out the basis for a reconceptualization of supplemental jurisdiction).

${ }^{72}$ To see that the ALI Draft proceeds upon the same interpretative assumption as the Abbott Laboratories and Stromberg courts, consider its discussion of proposed section 1367(c), which performs the same function as current section 1367(b) in reining in the grant of supplemental jurisdiction in an earlier section. See id. at 58-59. In the 
The draft itself acknowledges as much, in the course of questioning the legitimacy of "the sort of pragmatic discretion rather than express legislative command that long colored the whole realm of diversity jurisdiction." ${ }^{73}$ Viewing the days of such pragmatic discretion as numbered, the ALI Draft notes that " $[t]$ he legitimacy of this pragmatic discretion was questioned in [Finley], and the enactment the following year of present $\S 1367$ substituted a new regime of close attention to the literal text and plain meaning of the statutory conferral of supplemental jurisdiction. ${ }^{74}$ The ALI Draft carries this new regime of close attention to literal text to its logical conclusion, specifying in some detail the way in which its rules of supplemental jurisdiction play out in a variety of different contexts. One can quibble with certain of the choices in the ALI Draft, and an enacting Congress might well tinker with its provisions. Ultimately, though, a decision to adopt something like the ALI Draft would move the law of federal jurisdiction decisively away from a reliance upon pragmatic discretion and decisively into the realm of textual literalism.

Perhaps the combination of Finley and section 1367 leaves us with no alternative to an increasingly detailed jurisdictional code. But before we endorse the textual literalism of the ALI Draft, this Article proposes that we explore a more sympathetic approach to the interpretation of current section 1367. Such an approach may make it possible to retain the statutory underpinning of supplemental jurisdiction and to preserve some portion of the pragmatic discretion that had informed the evolution of the rules of diversity before the codification. It certainly avoids the textualist overkill of such cases as Abbott Laboratories and Stromberg.

\section{TOWARD A MORE SYMPATHETIC READING OF SECTION 1367}

Carefully read, section 1367 reveals no clearly expressed intention to alter the laws of diversity jurisdiction. Indeed, quite the contrary. Section 1367(a) appears to assume that the existing rules of complete diversity will continue to apply and that the grant of supplemental ju-

course of its analysis, the AII Draft describes current section 1367(a) as "imperfectly articulated in claim-specific terms"-terms that would have "revolutionary" consequences but for the restrictions in section 1367(b). Id at 58. Here, then, we see the same interpretation of section 1367(a) that characterizes the standard account of the statute-a broad grant of supplemental jurisdiction in diversity-party cases followed by a restriction on the grant. See supra note 16.

${ }^{73}$ ALI DRAFT, supra note 9 , at 65 .

${ }^{71}$ Id. 
risdiction will come into play only after the plaintiff has submitted claims that properly invoke such original jurisdiction. Consider again the language of the first sentence of subsection (a):

Except as provided in subsections (b) and (c) ... in any civil action of which the district courts have original jurisdiction, the district courts shall have supplemental jurisdiction over all other claims that are so related to claims in the action within such original jurisdiction that they form part of the same case or controversy. ${ }^{75}$

Literally read, this language provides for the assertion of supplemental jurisdiction only as to claims that bear a transactional relationship to the "claims" asserted in a "civil action" of which the district courts have "original jurisdiction." The statute thus appears to distinguish between joinder and aggregation issues that inform the existence of original jurisdiction and those that operate as part of the district courts' supplemental jurisdiction.

In this textual distinction lies the key to the sympathetic reading of section 1367. Before Finley, the Court had developed doctrines of pendent and ancillary jurisdiction that operated quite differently in federal-question and diversity proceedings. In federal-question cases, original jurisdiction attached to any well-pleaded complaint that asserted a substantial federal claim; pendent jurisdiction came quickly into play to govern the plaintiff's initial joinder of additional claims along the lines the Court developed for pendent claims in Gibbs (but rejected for pendent parties in Finley). In the pre-Finley world of diversity, by contrast, the rules of original jurisdiction (rather than of supplemental jurisdiction) governed a broad range of initial joinder and aggregation questions. ${ }^{76}$ Only after original jurisdiction attached in accordance with these fairly elaborate rules of complete diversity did the doctrine of ancillary jurisdiction come into play. One can thus read section 1367 (a) as having incorporated the rules of complete diversity into the statute's requirement that the district courts first obtain original jurisdiction of the cause. Sympathetically read, the statute would overrule Finley in federal-question. cases but would still enable the federal courts to retain the pre-Finley rules of diversity jurisdiction, in keeping with the views outlined in the House Report that accompanied the statute. ${ }^{77}$

${ }^{75}$ See supra note 43 (providing the text of section 1367).

${ }^{76}$ For a summary of the rules that govern the determination of diversity of citizenship and amount in controversy, see infra notes 77-87 and accompanying text.

7 See H.R. REP. NO. 101-734, at 27-29 (1990) [hereinafter HOUSE REPORT] (explaining the need for and effects of the codification of supplemental jurisdiction). For 
This Part of the Article presents the argument for a sympathetic reading of section 1367 . It begins with a review of the rules of pendent and ancillary jurisdiction that developed before Finley; emphasizing the differing operation of those rules in federal-question and diversity proceedings. Next, this Part considers both textual and structural evidence that section 1367 preserves and incorporates these pre-Finley differences. Finally, this Part tests the sympathetic reading in light of predictable arguments against its adoption and concludes that the sympathetic reading outperforms the standard account of the statute.

\section{A. PreFinley Distinctions in the Operation of Supplemental Jurisdiction}

Despite conceptual similarities, the pre-Finley doctrines of pendent and ancillary jurisdiction remained quite distinct in the work of the Supreme Court. ${ }^{78}$ In addition to its preservation of the nominal distinction between pendent and ancillary jurisdiction, the Court flatly refused to apply pendent jurisdictional concepts to cases in diversity. ${ }^{79}$ Instead, the Court continued to apply rules of law that it had developed in the interpretation of 28 U.S.C. $\$ 1332$ 's ("section 1332") provision for the exercise of diverse-party jurisdiction. ${ }^{80}$ As a practical

the HOUSE REPORT's discussion of the preservation of diversity, see infra notes 104, 112.

${ }^{73}$ See supra text accompanying note 18 (discussing the Supreme Court's development of the doctrines of pendent and ancillary jurisdiction in a series of decisions running well back into the nineteenth century); see also PAUL M. BATOR ET AL., HART \& WECHSLER's THE FEDERAL COURTS AND THE FEDERAL SYSTEM 1685 n.1 (3d ed. 1988) (noting the distinction between pendent and ancillary jurisdiction: pendent jurisdiction applies to efforts by plaintiff" (as in Gibbs) to join with a federal claim a nonfederal claim over which the court has no independent basis of jurisdiction" while ancillary jurisdiction applies "with respect to claims asserted after the filing of the original complaint").

${ }^{79}$ It was broadly recognized that the pre-Finley federal-question doctrine of pendent jurisdiction did not apply to cases based on diversity of citizenship. See WRIGHT, supra note 19, at 158 (noting that most pre-Finley courts "recognized that whatever the merits, or lack thereof, of th [e] concept [of pendent jurisdiction] to bring in additional parties in cases in which there is a federal question or to overcome problems of amount in controversy, it was not properly used to avoid the longstanding requirement of complete diversity"); McLaughlin, supra note 1, at 869 (noting that in pre-Finley pendent-claim jurisdiction the freestanding claim was a "federal law claim" and distinguishing ancillary jurisdiction as applicable to both federal-question and diversity jurisdiction).

${ }^{80}$ See, e.g., Zahn v. International Paper Co., 414 U.S. 291, 29498 (1973). The Zahn Court concluded that its interpretation of the term "matter in controversy" in the diversity statute required each member of the class to set up a claim that met the amount-in-controversy requirement and so refused to apply the doctrine of supple- 
matter, the refusal to import pendent jurisdiction concepts into diversity litigation meant that issues of transactional relationship and litigation convenience-the coin of the realm for supplemental jurisdiction-had far less to do with the scope of the claims a plaintiff might permissibly join in a diverse-party proceeding than the established rules of aggregation and complete diversity that the Court had worked out long before Gibbs came down in 1966.

Consider first the well-established complete-diversity requirement of Strawbridge v. Curtiss. ${ }^{81}$ Chief Justice Marshall's cryptic opinion in Strawbridge has come to stand for the proposition that citizens of the same state may not appear on opposing sides of an action within the diversity jurisdiction of the federal trial courts. ${ }^{82}$ Although it applies chiefly to section 1332 and does not control the scope of Congress's power under the diversity grant in Article III $^{83}$ the complete-diversity rule operated to preclude the assertion of many forms of pendentparty jurisdiction in the diversity context. Thus, a citizen of Illinois may sue a citizen of Texas and properly invoke diversity of citizenship as the basis of jurisdiction. But the Illinois citizen may not join an additional plaintiff from Texas, or an additional defendant from Illinois, even if the claims by and against these additional parties would satisfy the transactional tests of Rule 20 and Gibbs. ${ }^{84}$ In a complete-diversity inquiry, then, pendent-party jurisdiction would have no application.

The rules of aggregation similarly confirm the inapplicability of pendent jurisdiction to claims in diversity. Consider first the aggregation rule that permits a plaintiff to join a series of claims against a diverse defendant to satisfy the jurisdictional amount. Quite in contrast to the rules of pendent jurisdiction in Gibbs, the aggregation rules do not require any transactional relationship among the aggregated claims. ${ }^{85}$ Nor do they require that any one of the aggregated claims satisfy the jurisdictional threshold on its own; the law requires only

mental (ancillary) jurisdiction to permit the joinder of related, but below-threshold, claims by class members. Id. at 294-98.

${ }^{81} 7$ U.S. (3 Cranch) 267 (1806).

${ }^{82}$ See id. (holding that jurisdiction based on diversity requires "complete diversity"); see alsoWRIGHT, supra note 19, at 156 (illustrating the complete-diversity rule).

${ }_{83}$ See, e.g., State Farm Fire \& Cas. Co. v. Tashire, 386 U.S. 523, 530-31 (1967) (holding that the complete-diversity rule does not apply to actions brought under the authority of the interpleader statute, 28 U.S.C. $\$ 1335$, and upholding the constitutionality of the minimal diversity approach of the interpleader statute).

${ }^{84}$ See WRIGHT, supra note 19 , at 156 (illustrating the operation of the completediversity rule in similar terms).

${ }^{85}$ See id. at 210 (noting the absence of any requirement that claims aggregated to meet the amount-in-controversy threshold satisfy a test of transactional relationship). 
that the total value of all of the claims meets or exceeds the statutory minimum. ${ }^{86}$ Transactional relationship was equally irrelevant to the rules of aggregation that governed the joinder of additional parties. In Snyder v. Harris, the Court ruled that plaintiffs in a class action under Rule 23 may not aggregate the value of their several transactionally related claims to meet the amount-in-controversy requirement. ${ }^{87}$ The Court expressly based its decision on the statutory reference in section 1332 to the "matter in controversy" and held that each plaintiff's claim must meet the minimum amount. ${ }^{88}$ Similarly, as noted above, the decisions in Clark and Zahn preclude the assertion of jurisdiction over the jurisdictionally insufficient claims of co-plaintiffs, joined under Rules 20 and 23 respectively, even where one of the plaintiffs asserts a claim that meets the jurisdictional threshold. ${ }^{89}$ Like Snyder, Zahn refused to adopt a test of ancillarity, ${ }^{90}$ choosing instead to rely upon the established jurisdictional rules of diversity to determine the propriety of hearing the claims of the additional plaintiffs. ${ }^{91}$

In Finley itself, the Court noted this essential distinction between the operation of supplemental jurisdiction in federal-question and diversity proceedings. Although the Finley Court was willing to assume that the plaintiff's claims satisfied the constitutional "common nucleus" test for the assertion of pendent jurisdiction identified in Gibbs, it emphasized that the Gibbs test did not always control supplemental jurisdictional issues in different jurisdictional contexts. Pointing to Zahn as an example, the Finley Court noted that a transactional rela-

${ }^{85}$ See id. (explaining that unrelated claims, none of which meet the amount-incontroversy threshold, may be aggregated as long as the total value of the claims satisfies the threshold amount).

${ }^{87} 394$ U.S. 332 (1969).

s See id. at 336-39 (stating that "Congress has...consistently amended the amount-in-controversy section and re-enacted the 'matter in controversy' language without change of its jurisdictional effect against a background of judicial interpretation" which did not permit aggregation of "separate and distinct claims").

${ }^{89}$ See Zahn v. International Paper Co., 414 U.S. 291, $294-98$ (1973) (refusing to permit exercise of jurisdiction over the claims of unnamed class members, joined under Rule 23, that did not meet the jurisdictional threshold); Clark v. Paul Gray, Inc., 306 U.S. 583, 589 (1939) (refusing to permit exercise of jurisdiction over jurisdictionally insufficient claims of additional plaintiffs joined under Rule 20).

${ }^{90}$ See Zahn, 414 U.S. at 299 (noting that the doctrine of aggregation rests not upon the transaction-based joinder rules of the Federal Rules of Civil Procedure but on "this Court's interpretation of the statutory phrase 'matter in controversy"); Snyder, 394 U.S. at 336-37 (explaining that the doctrine of aggregation rests upon the Court's interpretation of the phrase "matter-in controversy" as precluding aggregation).

${ }^{91}$ See WRIGHT, supra note 19, at 214 (describing Zahn as the "death blow" to the lower court trend toward the application of the ancillarity principle to the determination of aggregation questions). 
tionship among claims did not alone suffice to establish the existence of jurisdiction over new parties. As the Finley Court noted in its account of Zahn, "we based this holding upon 'the statutes defining the jurisdiction of the District Court,' ... and did not so much as mention Gibbs."

\section{B. Rereading Section 1367 in Light of Pre-Finley Law}

The Court's continued emphasis on the applicability of the rules of diversity in cases like Snyder, Clark, and Zahn may explain why section 1367(a) draws a sharp distinction between "original jurisdiction" and "supplemental jurisdiction." In federal-question cases such as Gibbs and its progeny, original jurisdiction attached to a federal-law claim in the plaintiff's well-pleaded complaint; joinder of additional nonfederal claims triggered the application of the rules of supplemental (pendent) jurisdiction. But in diverse-party litigation, section 1332 and its collection of complete diversity and aggregation rules controlled the plaintiff's ability to join additional claims and parties. ${ }^{93}$

${ }^{92}$ Finley v. United States, 490 U.S. 545, 550 (1989).

${ }_{93}$ Under the rules that govern the timing of jurisdictional determinations in diversity, the federal court bases its determination as to the citizenship of the parties on the facts in the original complaint and does so as of the date of the filing of the action. See Freeport-McMoRan, Inc. v. K.N. Energy, Inc., 498 U.S. 426, 428 (1991) (discussing "the well-established rule that diversity of citizenship is assessed at the time the action is filed"). But jurisdiction does not attach at the outset for all time. If the plaintiff subsequently proposes to amend the complaint to join a nondiverse party, the district court must either reject the amendment or dismiss (or remand) the action. See, e.g., Hensgens v. Deere \& Co., 833 F.2d 1179, 1181-82 (5th Cir. 1987) (specifying test for scrutiny of post-removal motion by plaintiff to add nondiverse defendant). Similarly, the district court must dismiss the action if a nondiverse party proposed for joinder meets the test of indispensability. See Horn v. Lockhart, 84 U.S. 570, 579 (1873) (stating that where nondiverse parties are not indispensable, dismissing such parties is preferable to joining them and then dismissing the action for lack of subject matter jurisdiction). The district court, moreover, must align the parties in accordance with their real interest in the action and must dismiss the action if, as realigned, the parties do not satisfy the diversity requirement. See, e.g., Indianapolis v. Chase Nat'l Bank, 314 U.S. 63, 69, 74-75 (1941) (explaining that " [d]iversity jurisdiction cannot be conferred upon the federal courts by the parties' own determination of who are plaintiffs and who are defendants"). Finally, although the district and appellate courts can dismiss any non-indispensable parties whose presence would otherwise defeat diversity (jurisdictional "spoilers"), the remaining parties must satisfy the requirements of diversity. See Newman-Green, Inc. v. Alfonzo-Larrain, 490 U.S. 826, 837 (1989) (holding that "courts of appeal have the authority to dismiss a dispensable nondiverse party," but noting that, at the appellate level, such authority should be "exercised sparingly."). See generally WRIGHT, supra note $19, \$ \S 28-30$, at $171-80$ (explaining when parties' diversity is determined, which parties are considered in that determination, and a court's ability 
District courts sitting in diversity in the pre-Finley era would have had no occasion to consider supplemental jurisdictional issues until after the plaintiff had filed a complaint with claims and parties aligned in ways that satisfied the settled rules of original jurisdiction in section $1332 .^{94}$ Section 1367(a), with its requirement that "original jurisdiction" first attach to the "claims" in a civil action before the court may invoke supplemental jurisdiction, thus incorporates the pre-Finley law distinguishing original from supplemental jurisdiction in diversity. ${ }^{95}$

The same statutory distinction between original and supplemental jurisdiction applies to federal-question litigation but carries less significance in that context. As we have seen, a plaintiff with a substantial federal-law claim under Gibbs was free to invoke the district court's original jurisdiction over that claim and its supplemental jurisdiction over a related nonfederal claim in the same well-pleaded complaint. Original jurisdiction concepts still control and still operate distinctly from supplemental jurisdiction concepts, but the original jurisdiction inquiry remains quite discrete and focuses entirely upon the existence of a substantial federal-law claim. ${ }^{96}$ To be sure, the Finley Court refused to extend the concept of supplemental jurisdiction to encompass a pendent claim against a new party, finding a lack of statutory authority in the provision that conferred original jurisdiction on the district courts in claims against the United States. But Congress re-

to realign parties).

${ }^{34}$ That supplemental jurisdiction operated differently in federal-question and diversity matters was a commonplace of the pre-Finley scholarship. See, e.g., Freer, supra note 2, at $62-63$ (describing the limits that complete diversity imposes on the plaintiff's joinder of additional parties; noting the absence of any similar restriction in federalquestion matters; and concluding that courts would have no occasion to reach a pendent-party jurisdiction issue in diversity since the requirements of original jurisdiction would not have been met).

${ }_{95}$ Cf. Peterson v. BASF Corp., 12 F. Supp. 2d 964, 970-71 (D. Minn. 1998) (invoking legislative history to reject claim that section 1367 overrules Zahn and suggesting that section 1367(a) may incorporate some complete-diversity limits from prior law). I am indebted to Professor Steinman, who read an early draft of this Article, for bringing the Peterson decision and its reference to the possible incorporation of diversity limits in section 1367(a) to my attention.

${ }_{96}$ Professor Freer made precisely this point, writing some years before the Finley decision and the adoption of section 1367. Professor Freer first noted that pendentparty concepts had no application to diversity litigation, in light of the completediversity rule. He then distinguished federal-question proceedings, noting that "where original jurisdiction is based on the general federal-question statute, the pendent-party case will present a supplemental jurisdiction problem ...." Freer, supra note 2, at 63. In suggesting that section 1367 (a) differentiates between diversity and federal-question proceedings, in short, the argument in the text simply urges that the statute carried forward distinctions that the prior law of original and supplemental jurisdiction had recognized. 
sponded to that restrictive conception of supplemental jurisdiction by expressly declaring in section 1367 (a) that "[s] uch supplemental jurisdiction shall include claims that involve the joinder or intervention of additional parties. ${ }^{97}$ Congress cured the Finley problem, in short, by redefining supplemental jurisdiction to include additional parties and left the rules of original jurisdiction alone. ${ }^{98}$

This sympathetic reading of section 1367 (a) in light of prior law has a series of important implications for the interpretation of supplemental jurisdiction under the new statute. Perhaps most significantly, the sympathetic reading preserves the rules of complete diversity and aggregation that the Court had developed in the course of construing section 1332. As a gloss on the provisions of section 1332, these rules were understood to govern the plaintiff's joinder of claims and parties in diversity litigation brought within the original jurisdiction of the district courts. Section 1367(a) appears to incorporate all of these rules of joinder and aggregation by referring to civil actions "of which the district courts have original jurisdiction." The language of the statute suggests a neat, if not entirely logical or conceptually consistent, ${ }^{100}$ distinction between the rules of original jurisdiction in diversity that were to govern the plaintiff's joinder and aggregation of claims and parties and the rules of ancillary jurisdiction that were to control the defendant's joinder of claims and parties in subsequent pleadings.

In preserving a broader array of rules to govern original jurisdiction over additional claims and parties in diversity than in federalquestion proceedings, section 1367 (a) leaves in place a distinction between pendent and ancillary jurisdiction that had grown up in prior cases. As we have seen, the pre-Finley decisions steadfastly refused to apply pendent jurisdiction concepts to diversity maiters. Rather, the established body of law governing complete-diversity and aggregation continued to govern the plaintiff's initial assertion of claims. The ref-

${ }^{97} 28$ U.S.C. $\$ 1367$ (a) (1994). Commentators agree that the statute accomplished the goal of overturning Finley by including this explicit provision for the exercise of pendent-party jurisdiction. See, e.g., Freer, Life After Finley, supra note 3, at 473 (approving of the implicit overruling of Finley).

${ }^{38}$ On this account, then, the statute directly overrules Finley by including additional parties within the ambit of supplemental jurisdiction that the plaintiff may invoke, as in Gibbs, at the initial pleading stage.

${ }^{99}$ See supra note 43 (setting forth the text of section 1367).

${ }^{100}$ For a criticism of this absence of conceptual consistency, see ALI DRAFT, supra note 9, at xvi, 58 (describing current section 1367 as "imperfectly articulated in claimspecific terms"). 
erence in section 1367 (a) to the necessity of first securing "original jurisdiction" makes it clear that these joinder and aggregation rules would continue to control in diversity litigation. The provision for the exercise of supplemental jurisdiction over claims related to those "within such original jurisdiction" can only sensibly refer, at least in the diversity context, to the established doctrine of ancillary jurisdiction, which traditionally applied to the claims and parties joined in subsequent pleadings filed by defendants and intervening parties. ${ }^{101}$

This sympathetic reading of section 1367 (a) fits well with the language and structure of subsequent provisions of section $1367 .{ }^{102}$ Consider first the provisions of section 1367 (b), which specify a variety of situations in which the district courts, sitting in diversity, may not exercise the supplemental jurisdiction that has been conferred upon them in subsection (a). The statute bars such jurisdiction "over claims by plaintiffs against persons made parties under Rule 14, 19, 20, or 24 " of the Federal Rules and over "claims by persons proposed to be joined as plaintiffs under Rule 19" when exercising such jurisdiction would be inconsistent with the jurisdictional requirements of section 1332. ${ }^{103}$ The statute reflects a concern with the preservation of the rules of diversity and a desire to preclude the grants of supplemental (ancillary) jurisdiction from eroding those rules.

More than merely confirming a general spirit of cautious restatement, subsection (b) offers strong structural support for a sympathetic interpretation of the scope of subsection (a)'s grant of supplemental jurisdiction in diversity. The exceptions specified in subsection (b) operate as a bar to the assertion of jurisdiction over claims that plain-

${ }^{101}$ See McLaughlin, supra note 1, at 874 (noting that ancillary jurisdiction applies to claims "asserted in an ongoing federal lawsuit after the filing of the original complaint" "); FRIEDENTHAL ET AL., supra note 19, §§ 2.12, 2.14 at 65-67, 76-81 (same).

102 It bears noting that the distinctive operation of supplemental jurisdiction in federal-question and diversity matters parallels a well-known distinction in these two familiar sources of judicial power. As Chief Justice John Marshall noted, Article III of the Constitution distinguishes between federal-question "cases" (jurisdiction "depends on the character of the cause," and not on the identity of the parties) and party-based "controversies" ("jurisdiction depends entirely on the character of the parties"). Cohens v. Virginia, 19 U.S. (6 Wheat) 264, 378 (1816). See generally James E. Pfander, Rethinking the Supreme Court's Original Jurisdiction in State-Party Cases, 82 CAL. L. REV. 555, 604-17 (1994) (discussing the distinction and its implications for the interpretation of Article III). Even though this constitutional distinction has no immediate relevance to the proper interpretation of the statute, it may help to explain why the doctrine of pendent parties met resistance in the diversity context. Cf. Freer, supra note 2, at 62-63 (noting the difference between the subject-matter focus of federal-question jurisdiction and the party-based focus of diversity jurisdiction).

${ }^{103}$ See supra note 43 (setting forth section 1367). 
tiffs would propose to bring, not in the first instance, but in response to other claims that have been inserted into the proceeding by other parties. Subsection (b)'s exception for claims by plaintiffs against persons made parties under Rule 14 offers a definitive illustration. All commentators agree that the reference to Rule 14 codifies the Supreme Court rule in Kroger, ${ }^{104}$ a case in which the Court refused to permit the district court to assert ancillary jurisdiction over the plaintiff's claim against a nondiverse party joined by the defendant under Rule $14{ }^{105}$ The Kroger Court laid special emphasis on the fact that the ordinary rules of diversity jurisdiction would bar the plaintiff from asserting claims against the nondiverse defendant in the first instance. ${ }^{106}$ Unwilling to permit an end-run around this rule of complete diversity, the Kroger Court adopted a narrow interpretation of ancillary jurisdiction. Although the Court seemingly agreed to permit the assertion of ancillary jurisdiction over the impleader claims of defendants under Rule 14, and in other settings, ${ }^{107}$ the Court refused to countenance the expansion of ancillary jurisdiction to encompass a Rule 14 claim by the plaintiff against the newly impleaded defendant.

Notice how closely the underlying structure of section 1367 follows the rationale of Kroger. Subsection (a), sympathetically read, preserves the rules of complete diversity and confers supplemental (ancillary) jurisdiction over new claims and parties joined in pleadings subsequent to the plaintiff's initial complaint. But subsection (b), like Kroger, creates a restriction on the scope of such ancillary jurisdiction to preserve the essential features of the complete diversity requirement. In other words, the ancillary focus of the exceptions in subsection (b) tends to confirm that the grant of supplemental jurisdiction in subsection (a) operates in effect as a grant of ancillary jurisdiction. ${ }^{108}$ Because Congress had preserved the rules of complete diver-

${ }^{104}$ See, e.g., McLaughlin, supra note 1, at 935-38 (describing the manner in which section 1367(b) codifies and extends the rule of Kroger).

${ }^{105}$ See Owen Equip. \& Erection Co. v. Kroger, 437 U.S. 365, 377 (1978) (holding that the "policy of [section 1332] calls for its strict construction" and that "[t]o allow the requirement of complete diversity to be circumvented as it was in this case would simply flout the congressional command" (citations omitted)).

${ }^{106}$ Id at 373-74 (citing Strawbridge and Zahn).

${ }^{107} I d$ at 375 n.18 (citing with apparent approval lower court decisions that had asserted ancillary jurisdiction over compulsory counterclaims, cross-claims, impleader claims, and claims by intervenors as of right).

${ }^{109}$ The remaining exceptions in section 1367 (b) also focus on the containment of ancillary jurisdiction. In foreclosing jurisdiction over claims by plaintiffs against persons joined under Rules 19 and 24, subsection (b) seeks to preserve the rule that ancillary jurisdiction does not extend to necessary parties (Rule 19) and to produce the 
sity and aggregation in subsection (a), it was simply unnecessary for Congress to establish exceptions in subsection (b) other than those necessary to rein in the scope of ancillary jurisdiction and to preserve the result in Kroger.

\section{Testing the Sympathetic Reading}

\section{The Grant of Supplemental Jurisdiction}

Notwithstanding the tight fit between the sympathetic reading and the language, structure, and legislative history of the statute, ${ }^{109}$ one can imagine plausible, if ultimately unconvincing, arguments against the interpretation. Consider first the argument that, by using the term "supplemental jurisdiction" in section 1367(a), Congress must have intended to bring the doctrines of pendent and ancillary jurisdiction into congruence rather than to preserve their differences under a new label. On this account, the plenary grant of supplemental jurisdiction in section 1367(a) operates identically in both federalquestion and diversity cases and extends to the boundaries of a consti-

same result with respect to those who intervene as defendants (Rule 24). See generally Rowe et al., A Reply, supra note 3, at 955-59 (discussing the statute's resolution of the necessary-party/intervention anomaly). Original diversity jurisdiction did not attach to such claims under pre-Finley decisional law; rather, such claims were analyzed under the rules of ancillarity. See, e.g., 7 CHARLES ALAN WRIGHT ET AL., FEDERAL PRACTICE AND PROCEDURE $\$ 1610$, at 150-54 (2d ed. 1986) (treating, in pre-Finley discussion, the Rule 19/24 anomaly as a question of ancillary jurisdiction). For an ancillary interpretation of the reference to Rule 20, see infra notes 113-19.

${ }^{109}$ If the language and structure of the statute reveal a desire on the part of Congress to maintain the rules of diversity and to authorize ancillary jurisdiction only insofar as that jurisdiction poses no threat to those rules, then the legislative history provides additional confirmation. The House Judiciary Committee Report explains that the statute responds to Finley by providing statutory authority to hear supplemental claims, including claims involving the joinder of additional parties. But the Report also suggests quite clearly that its codification of the rules of supplemental jurisdiction will preserve an existing distinction between federal-question and diversity litigation:

In federal-question cases, it broadly authorizes the district courts to exercise supplemental jurisdiction over additional claims, including claims involving the joinder of additional parties. In diversity cases, the district courts may exercise supplemental jurisdiction, except when doing so would be inconsistent with the jurisdictional requirements of the diversity statute.

HOUSE REPORT, supra note 77, at 28. The Report thus confirms that the statute leaves in place the rules governing the assertion of original jurisdiction in diversity proceedings, including the rules of joinder and aggregation that govern original jurisdiction of the plaintiff's initial complaint. The same conclusion emerges from the Report's further statement that the "section is not intended to affect the jurisdictional requirements of 28 U.S.C. $\S 1332$ in diversity-only class actions, as those requirements were interpreted prior to Finley." Id. at 29. 
tutional "case" under Article III. ${ }^{110}$ Something like this argument, or this unspoken assumption, informs virtually every published account of section 1367 and deserves to be taken seriously. ${ }^{111}$ Indeed, many observers who have otherwise found much to criticize in the statute have applauded Congress's decision to end the pendent/ancillary distinction through adoption of the supplemental label. ${ }^{12}$

I share the view that we should strive for doctrinal coherence in the application of supplemental jurisdiction concepts, but I do not believe that such a goal requires that we view the use of the term supplemental jurisdiction as reflecting a congressional decision to import pendent jurisdictional concepts into diversity litigation. On my account of the statute, supplemental jurisdiction can operate just as it did in the pre-Finley era. In federal-question litigation, the rules of original jurisdiction require only a substantial federal-law claim for supplemental (pendent) jurisdiction to support the adjudication of the plaintiff's additional, nonfederal claims. In diversity litigation, by contrast, the rules of original jurisdiction govern joinder and aggregation issues in the plaintiff's complaint and supplemental (ancillary) jurisdiction applies to the subsequent joinder of claims and parties. In conceptual terms, supplemental jurisdiction operates in the same way in both settings, coming into play only after the demands of original jurisdiction have been satisfied and applying to claims that satisfy the transactional relationship test of Article III. On this account, the same test of transactional relationship might well apply in both the federal-question and diversity contexts, thus achieving a measure of doctrinal coherence. At the same time, section 1367(a)'s preservation of the rules of original jurisdiction would, at least in diversity proceedings, defer the application of this supplemental jurisdictional analysis until after the complaint passed muster. It may well prove useful to continue to talk of pendent and ancillary jurisdiction to keep these distinctions straight, as many scholars have done in writing about the operation of the statute. ${ }^{113}$ Still, the crucial statutory dis-

${ }^{110}$ See supra note 43 (setting forth the text of section 1367).

"See supra note 16 (citing articles which view subsection (a) as a broad grant of supplemental jurisdiction).

${ }^{112}$ See, e.g., Freer, Life After Finley, supra note 3, at 473 (noting that the use of the term "supplemental jurisdiction" reflects a "clear trend" in case law and academic literature); McLaughlin, supra note 1, at 860 (referring to the abolition of the pendent and ancillary labels as "beneficial").

${ }^{113}$ See, e.g., McLaughlin, supra note 1, at 925 (noting that the statute can be understood by referring to the former doctrines of pendent-claim, pendent-party and ancillary jurisdiction). 
tinction lies in its incorporation of the rules of original jurisdiction, which govern a much broader array of joinder and aggregation issues in diversity than in federal-question litigation. Once jurisdiction attaches, the statutory grant of supplemental jurisdiction may operate in much the same way in a variety of settings. What we used to think of as ancillary jurisdiction, for example, would continue to be available in both federal-question and diversity litigation. ${ }^{114}$

One can, in short, read Congress's decision to provide for the exercise of "supplemental jurisdiction" as something other than a directive to achieve precisely the same outcomes in both federal-question and diversity litigation. Congress did not express any desire to change the manner in which the doctrine operates in discrete cases (aside from its provision for the exercise of supplemental jurisdiction over additional parties). After all, the statute did not coin the term "supplemental jurisdiction"; scholars had previously used the term to refer to both pendent and ancillary jurisdiction. ${ }^{115}$ The statute's use of the phrase, therefore, conveys no desire to change the established operation of the underlying doctrine. Indeed, the Finley decision itself invoked a canon of construction under which a codification of existing jurisdictional practices would presumptively carry forward past interpretations unless that statute contains some clear expression of congressional intent to depart from the settled rule. ${ }^{116}$ One can scarcely discover an intent to change the law in Congress's decision to use the supplemental label standing alone, particularly in view of its drafters' avowed desire to avoid controversy. If one were inclined to consider it, moreover, the legislative history expressly disclaims any intention to make broad changes in the law. ${ }^{17}$

${ }^{114}$ See id. at 874 (noting that, unlike pendent jurisdiction, ancillary jurisdiction applied whether the original jurisdiction claim was founded on a federal question, diversity of citizenship, or some other basis).

${ }^{115}$ See supra note 2 (citing earlier use of the term "supplemental jurisdiction").

${ }^{116}$ See supra note 42 (discussing Finley).

${ }^{117}$ The clearest evidence in the legislative history appears in the House Judiciary Report, which includes the following statement:

The doctrines of pendent and ancillary jurisdiction, in this section jointly labeled supplemental jurisdiction, refer to the authority of the federal courts to adjudicate... [nonfederal] claims [that meet the test of $G i b b s] . .$.

....

... This section would authorize jurisdiction in a case like Finley, as well as essentially restore the pre-Finley understandings of the authorization for and limits on other forms of supplemental jurisdiction.

HOUSE REPORT, supra note 77, at 27-28. These statements, in a Report that emphasizes a desire on Congress's part to restore understandings of the "limits" on other, preFinley forms of supplemental jurisdiction, provide the backdrop for a sympathetic read- 
The congressional disclaimer corresponds to the conclusion that emerges from a consideration of the correspondence among the drafters of the supplemental jurisdiction statute. In the Explanation that accompanied a discarded version of the statute, the authors expressly stated that the "purpose of the proposal is to codify the judicially created doctrines of pendent and ancillary jurisdiction as the Federal Courts Study Committee recommended."118 In reviewing that draft, one of the three principal drafters of the final version of section 1367 expressed "complete support" for the proposal to "codify the doctrines of pendent and ancillary jurisdiction." ${ }^{\text {n19 }}$ Although the terms of the codification changed over the course of the next few weeks, the correspondence of the drafters reveals no departure from this fundamental desire to codify pendent and ancillary jurisdiction. Indeed, the apparent focus of the drafters was to rewrite the draft statute to preserve the rule in Kroger and to bring the rules governing the assertion of diversity jurisdiction over parties joined under Rules 19 and 24 into congruence with Kroger's spirit. ${ }^{120}$

ing of the statute.

${ }_{118}$ Hearing on H.R. 5381 Before the Subcomm. on Courts, Intellectual Property, and the Administration of the Justice of the House Comm. on the Judiciary, 101st Cong. 689 (1990) [hereinafter Hearing] (Explanation of the Proposal to Codify Supplemental Jurisdiction accompanying Letter from Arthur D. Wolf, Professor, Western New England College School of Law, to Robert W. Kastenmeier, Chairman, Subcommittee on Courts, Intellectual Property, and the Administration of the Justice (June 8, 1990)). Although the Wolf draft appeared in H.R. 5381 as late as September 6, 1990, Congress later chose to adopt a substitute measure that was largely the work of Professors Mengler, Rowe, and Burbank. See Fairman, supra note 4, at 160-70 (recounting the progression of drafts from that of Wolf, to the substitute of Judge Weis, and finally to the September 11, 1990 draft that became law).

119 Letter from Thomas M. Mengler, Professor, University of Illinois at UrbanaChampaign College of Law, to Robert W. Kastenmeier, Chairman, Subcommittee on Courts, Intellectual Property, and the Administration of the Justice (June 13, 1990), in Hearing, supra note 118, at 701.

${ }^{120}$ One can see this focus on the problems associated with diversity jurisdiction and the preservation of Kroger in the correspondence of Professor Burbank, Professor Mengler, and Professor Kramer, a consultant to the Federal Courts Study Committee. See Letter from Stephen B. Burbank, Professor, University of Pennsylvania Law School, to Thomas M. Mengler, Professor, University of Illinois at Urbana-Champaign College of Law (Aug. 14, 1990), in Hearing, supra note 118, at 706-07 (raising the question of whether Kroger would be overruled by the proposed statute); Letter from Thomas M. Mengler to Stephen B. Burbank (August 24, 1990), in Hearing, supra note 118, at 70809 (affirming that the proposed language would overrule Kroger); Letter from Larry Kramer, Professor, University of Michigan Law School, to Joseph F. Weis Jr., Judge, United States Court of Appeals for the Third Circuit (Aug. 31, 1990), in Hearing, supra note 118, at 713, 714-15 (arguing that an early draft of section 1367(b) that had appeared in the working papers of the Federal Courts Study Committee and that ultimately became the vehicle the drafters relied upon in crafting the statute avoided the problem of overruling Kroger by "preserving pre-Finley limitations on pendent jurisdic- 
One finds an echo, perhaps unconscious, of the drafters' desire to preserve the distinction between pendent and ancillary jurisdiction in the terms of the statute itself. The statute refers to the existence of original jurisdiction over the "claims" in a "civil action" and thus appears to reject the notion that a single, jurisdictionally sufficient claim will support the exercise of plenary pendent jurisdiction in diversity matters. Previous decisions as to the scope of diversity jurisdiction scrutinized the claims and parties in the action as a whole for compliance with the requirements of section 1332; as noted above, a single, jurisdictionally sufficient claim would not have supported the joinder of nondiverse parties or jurisdictionally insufficient claims. In its focus on the need for jurisdiction over the claims in a civil action, section 1367 decisively differs from the conceptual apparatus of the ALI Draft. The ALI Draft aims to transform the operation of supplemental jurisdiction by treating any jurisdictionally sufficient claim (including one in diversity) as a "freestanding" claim that will, by definition, support the assertion of jurisdiction over supplemental claims that satisfy the case-or-controversy test of relatedness. There may be good reasons to shift from an action-specific focus to a claim-specific focus, as the ALI Draft suggests, but there is no reason to believe that Congress had anticipated that change in the law when it enacted section 1367. Rather, the statute appears to preserve the action-specific focus of the rules of complete diversity and aggregation that had evolved up to that point.

\section{Jurisdiction over Civil Actions and the Overruling of Finley}

To the extent that section 1367 (a) operates in diversity only after the district court first secures original jurisdiction over the civil action, one might doubt its effectiveness in overruling Finley in federalquestion cases. ${ }^{121}$ Finley held that the jurisdiction of the district courts under the FTCA extends to claims against the United States but does not reach related state-law claims against nondiverse pendent parties. ${ }^{122}$ Section 1367(a) set out to overrule Finley by conferring supplemental jurisdiction on the district courts and by making it clear that such jurisdiction includes claims against new parties. But as we have seen, the statute provides for the assertion of supplemental jurisdiction only after the district court has acquired original jurisdiction over the civil action. So while a district court was free (before section

tion in diversity cases").

${ }^{121}$ I am indebted to David Shapiro for drawing this possibility to my attention.

${ }^{122}$ See supra notes $36-42$ and accompanying text (describing Finley's holding). 
1367's enactment) to exercise original jurisdiction over a federalquestion claim against a single defendant, Finley itself concluded that such original jurisdiction did not extend to related state-law claims against additional, nondiverse parties. ${ }^{123}$ Lacking original jurisdiction over all of the plaintiff's claims in the civil action, the district court in a case like Finley may appear to lack the statutory predicate for bringing section 1367 (a)'s grant of supplemental jurisdiction into play. In other words, as one treatise noted in analyzing the problem addressed here, "if the courts applied the language of $\S 1367$ (a) literally, it would defeat the main purpose of the statute-overruling Finley." "124

In contrast, I believe that the literal terms of section 1367(a) can both preserve the rules of original jurisdiction in diversity and secure the overruling of Finley. Although Finley ruled out pendent-party jurisdiction in federal-question cases, it did leave pendent-claim jurisdiction and the rule of Gibbs intact. ${ }^{125}$ The preservation of Gibbs, however, coexists uneasily with the Finley Court's emphasis on the need for written statutory authority; the absence of written authority that Finley read to foreclose jurisdiction over claims against pendent parties appeared to many to plague the assertion of pendent-claim jurisdiction as well. ${ }^{126}$ The drafters of section 1367 (a) thus set out to provide statutory authority for both Gibbs and Finley and did so in that portion of the statute that confers supplemental jurisdiction over "all other claims that are so related to claims in the action within such original jurisdiction that they form part of the same case or controversy under Article III." This language, clearly meant to codify Gibbs, assumes that the district court will hear pendent claims in a federal-question proceeding not as part of the court's original jurisdiction over a civil action but as part of the statutorily conferred grant of supplemental jurisdiction. ${ }^{127}$ The statute thus resolves the anomalous status of Gibbs

${ }^{123}$ See Finley v. United States, 490 U.S. 545, 553, 556 (1989).

124 LARRY L. TEPLY \& RAIPH U. WHITTEN, GIVII PROCEDURE 124 (1994).

125 See Finley, 490 U.S. at 549-51, 556 (distinguishing pendent-claim from pendentparty jurisdiction and expressing no desire to impair the continuing vitality of Gibbs, despite the fact that it departed from past practice in asserting jurisdiction without statutory authority).

${ }^{126}$ See supra note 42 and accompanying text (describing concerns over the breadth of Finley's holding).

${ }^{127}$ Most observers agree that the grant of supplemental jurisdiction over related claims in section 1367(a) codifies the pendent-claim jurisdiction rule in Gibbs. See, e.g., McLaughlin, supra note 1, at 925. Yet the logic of the action-specific focus that Professors Teply and Whitten rely upon in doubting the statute's effectiveness in overruling Finley would also render the statute essentially irrelevant to pendent-claim jurisdiction. See TEPLY \& WHITIEN, supra note 124, at 123-24. The Teply-Whitten approach reads 
after Finley by defining pendent-claim jurisdiction as part of the district court's supplemental, not original, jurisdiction. ${ }^{128}$

The statute's treatment of pendent claims as lying within the district court's supplemental jurisdiction helps to make clear that the statute authorizes supplemental jurisdiction over pendent parties as well. Immediately following the grant of supplemental jurisdiction, the statute provides that "[s] uch supplemental jurisdiction shall include claims that involve the joinder or intervention of additional parties." ${ }^{129}$ In effect, then, the statute provides for pendent-party jurisdiction by providing a statutory foundation for Gibbs, and by extending such jurisdiction to include the addition of new, pendent parties. It thus assumes that a single "freestanding" or jurisdictionally sufficient federal-question claim will bring into play the district court's supplemental jurisdiction over related claims; in other words, the statute continues and codifies the claim-specific approach to pendent jurisdiction in federal-question cases that the Gibbs Court had developed. Such an approach belies the argument that district courts must defer their inquiry into the existence of supplemental jurisdiction until after the rigorous original jurisdiction demands of Finley have first been met.

\section{The Rule 20 Wrinkle}

One might also argue that the sympathetic reading of the statute cannot well account for the appearance in subsection (b) of a provision that restricts supplemental jurisdiction over claims by plaintiffs

section $1367(a)$ as preserving pre-codification rules of supplemental jurisdiction in federal-question cases and would presumably include the Gibbs rule within the scope of the district courts' original jurisdiction. On such a reading, the grant of supplemental jurisdiction in section 1367 (a) over related claims would be redundant of jurisdiction already available as an original matter. It makes a good deal more sense, I submit, to read section 1367(a) as conferring supplemental jurisdiction over pendent claims and thus to confirm a claim-specific approach to federal-question jurisdiction.

${ }^{123}$ In describing Gibbs as anomalous after Finley, I simply mean to note that the rationale of Finley's insistence upon written statutory authorization raised doubts as to whether existing jurisdictional statutes conferred pendent-claim jurisdiction on the district courts. On the one hand, Finley expressly refused to treat the statutory grant of jurisdiction over a "civil action" as having acquired a judge-made gloss that included supplemental jurisdiction. See supra note 42 . On the other hand, the Finley Court expressed no desire to impair Gibbs. See supra note 125. Finley thus left it uncertain as to whether a district court's pendent-claim jurisdiction under Gibbs would come into play as part of its original jurisdiction or as part of supplemental jurisdiction.

12928 U.S.C. $\$ 1367$ (a) (1994). See supra note 43 for the full text of the statute. 
against persons made parties under Rule $20 .^{130}$ The Rule 20 exception plays a major role in the standard account of section 1367, operating as an important restriction on the otherwise broad grant of supplemental jurisdiction in diversity matters conferred in subsection (a). ${ }^{131}$ In contrast to the standard account, the sympathetic reading posits that section 1367 (a) incorporates the complete-diversity rules that preclude plaintiffs from joining additional, nondiverse defendants under Rule 20. If subsection (a) already precludes the plaintiffs from joining nondiverse defendants, one might plausibly ask why subsection (b) also includes language to foreclose the assertion of claims by plaintiffs against persons made parties under Rule 20. The standard account of the reference to Rule 20 in section 1367 (b), in short, appears to undermine the sympathetic reading of section 1367(a).

But one can develop a sympathetic alternative to the standard account of the Rule 20 reference that fits well with the interpretation of section 1367(a) proposed in this Article. Recall that section 1367(b) seeks to protect complete diversity from situations, like that in Kroger, in which plaintiffs seek to rely upon the district court's ancillary jurisdiction over claims they assert against nondiverse defendants that others have joined to the litigation. In its effort to prevent an erosion of complete diversity through such ancillary jurisdiction, section 1367(b) deliberately uses the passive voice. Subsection (b) does not directly bar plaintiffs from joining nondiverse defendants under Rule 20; rather, it declares that plaintiffs may not assert claims against "persons made parties" under Rule 20. The statute thus can be read to contemplate that the persons in question will have been made parties by someone other than the plaintiff; the language of section 1367 (b) literally addresses itself to the plaintiff's subsequent assertion of claims

${ }^{130}$ Rule 20 provides in relevant part that all parties may join as plaintiffs in an action "if they assert any right to relief... arising out of the same transaction, occurrence, or series of transactions or occurrences and if any question of law or fact common to all these persons will arise in the action"; the same transactional test governs the joinder of multiple defendants. FED. R. GT. P. 20(a).

${ }_{131}$ See, e.g., Stromberg Metal Works, Inc. v. Press Mech., Inc., 77 F.3d 928, 931-32 (7th Cir. 1996) (noting the Rule 20 limits on the otherwise broad scope of section 1367(a)); ALI DRAFT, supra note 9, at 68 (describing the effect of the reference to Rule 20 as withdrawing supplemental jurisdiction over claims against additional defendants joined under that rule, but as failing to withdraw such jurisdiction over claims by additional plaintiffs joined under the same rule and ascribing the difference in treatment to an error in drafting); Rowe et al., A Reply, supra note 3, at $961 \mathrm{n} .91$ (relying on the reference to Rule 20 in arguing that the statute preserved so much of the completediversity requirement as relates to the joinder of nondiverse defendants). 
against these new parties. ${ }^{132}$

The Federal Rules furnish examples of situations in which defendants may join additional parties under the transactional test of Rule 20: Rule 13(a) specifies that a defendant must assert an available, transactionally related "compulsory" counterclaim against an opposing party and Rule $13(\mathrm{~g})$ authorizes a cross-claim against a co-party. ${ }^{133}$ (Rule 14 incorporates similar joinder rules in permitting impleaded third-party defendants to set up counterclaims and cross-claims under Rule 13. $)^{134}$ Once a new claim has been asserted under these Rules, Rule 13(h) expressly permits a defendant to join additional defendants as parties to these counterclaims and cross-claims, ${ }^{135}$ so long as

${ }^{132}$ One can probably best explain the reference to Rule 20 as a drafting error; indeed, most accounts of the statute adopt that view. See, e.g., Rowe et al., A Reply, supra note 3, at $961 \mathrm{n} .91$ (describing the omission of claims by plaintiffs, joined under Rule 20, as a "far more serious" problem than others the critics had identified); Steinman, supra note 16, at 100-01 (raising doubts about the nature of the error and maintaining that Rules 15 and 21, rather than Rule 20, are the proper rules for adding parties postfiling). It appears that the error resulted from an excess of caution on the part of the drafters. Although they had framed a statute that sought to preserve the completediversity requirement, last-second concerns led them to add a reference to Rule 20 in the limiting provisions in section 1367(b). Compare Letter from Thomas M. Mengler, Professor, University of Illinois at Urbana-Champaign College of Law, to Thomas D. Rowe, Jr., Professor, Duke University School of Law (Aug. 28 1990), in Hearing, supra note 118, at 716-17 (describing his changes to a draft of 1367(b) and listing exceptions for claims by plaintiffs against parties joined under Rules 14, 19, and 24, but omitting any reference to Rule 20), with Draft, prepared by Thomas D. Rowe, Jr., Stephen B. Burbank \& Thomas M. Mengler, Sept. 11, 1990, in Hearing, supra note 118, at 722 (including in section 1367(b) an exception for claims against persons made parties under Rule 20 and suggesting that the addition of Rule 20 occurred in early September). See also Fairman, supra note 4, at 166-69 (tracing the progression of drafts and noting in particular that the reference to Rule 20 first appeared in the September 11 draft of Rowe, Burbank, and Mengler). Similar last-second concerns prompted the drafters to worry about their failure to include a restriction for claims joined under Rule 23. They caught the Rule 23 implications too late, however, to address with a change to the statutory language and so relied upon a curative reference in the legislative history instead. See Rowe et al., A Reply, supra note 3, at 960 n.90 (describing the attempt to address the Rule 23 problem through a curative reference in the legislative history). These concerns reflect an acceptance of what I have called the standard account, resting as they do on the view that section 1367(a) conferred a broad grant of supplemental (pendent-party) jurisdiction in diversity matters. The curative efforts reveal that the drafters did not read section 1367(a) itself as an adequate defense of the completediversity requirement.

${ }^{133}$ FED. R. CIV. P. 13(a), 13(g).

${ }^{134}$ FED. R. GV. P. 14(a).

135 FED. R. CIV. P. 13(h) (specifying that persons "other than those made parties to the original action may be made parties to a counterclaim or cross-claim in accordance with the provisions of Rules 19 and $20^{\prime \prime}$ ). Cf. TEPLY \& WHITIEN, supra note 124, at 132$33 \mathrm{n} .295$ (suggesting a similar interpretation of the Rule 20 reference as applicable to ancillary jurisdiction over parties joined under Rule 13(h)). 
the claims against such new parties satisfy the transactional test of Rule 20. ${ }^{136}$ Section 1367(a) extends the district court's ancillary jurisdiction to the claims that defendants assert against such newly joined parties. But the Rule 20 exception in section 1367(b) can be read to follow Kroger in refraining from permitting the plaintiffs to assert claims against them in circumstances that might erode the complete diversity requirement ${ }^{137}$ So read, the Rule 20 exception conforms to the general thrust of section 1367(b), which, sympathetically read, operates not as a constraint on what the plaintiff does in the initial complaint but on what the plaintiff does later with respect to subsequently joined parties.

Although a sympathetic reading of the Rule 20 exception does not conform to the drafters' understanding of section $1367(\mathrm{~b})$ 's operation, it may make as much sense as the standard account. For one thing, the standard account of the Rule 20 exception contains its own shortcomings. Most importantly, the exception fails to preclude the plaintiff from filing a diversity action and later moving to join additional, nondiverse plaintiffs under Rule 20 as parties within the grant of supplemental jurisdiction in section 1367(a). The sympathetic account of the statute avoids what the drafters rightly termed this "gaping hole" in the complete-diversity rule. ${ }^{138}$ Moreover, the sympathetic account of the Rule 20 exception makes better sense of the subsequent language in section 1367(b). Recall that section 1367(b) does not operate as a flat bar to the assertion of supplemental jurisdiction

${ }^{136}$ FED. R. CTV. P. 13(h). To be sure, some observers have taken issue with functional interpretation of the reference in section 1367 to Rule 20, arguing that its rule of transactional relationship for the joinder of parties does not actually provide a measure of the propriety of such joinder in the context of pending litigation. See Steinman, supra note 16, at 100-01 (arguing that Rule 20 joinder does not apply to the addition of parties post-filing). These observers argue that the statute should have referred instead to Rule 15 as the rule that actually provides the standard for leave to amend the pleadings to add additional parties. Id. I do not share this criticism of the statute's reference to Rule 20. All of the rules referred to in the statute set forth a test of transactional relationship. It is these tests of transactional relationship, and not general standards for amendment of the pleadings, that inform the questions of joinder and supplemental jurisdiction in the course of motions for leave to amend under Rule 15.

${ }^{137}$ Of course, one might argue that the proposed interpretation of the Rule 20 reference suffers from redundancy insofar as it incorporates the joinder rules in Rule 14, which appears as a separate exception in section 1367(b). Yet one can see the rules as performing discrete functions: the reference to Rule 14 incorporates the test for the impleader of third-party defendants (as in Kroger) and Rule 20 governs the assertion of claims against parties added to the litigation in connection with counterclaims and cross-claims allowed under Rule 13.

${ }^{133}$ See supra note 65 (quoting the statute's drafters). 
over claims by plaintiffs but only bars the jurisdiction when it would be "inconsistent with the jurisdictional requirements of section 1332." ${ }^{139}$ One has difficulty seeing how a district court could possibly find that an action in which plaintiffs have invoked Rule 20 to join nondiverse defendants would be consistent with the complete diversity rules of Strawbridge $v$. Curtiss. But the assertion of claims by plaintiffs against persons made parties under Rule 20 by someone other than the plaintiff might have a less dramatic tendency to erode the complete diversity rule, at least so long as the proposed joinder did not present the threat of strategic manipulation that persuaded the Court to enforce the complete diversity rule in Kroger.

\section{Applying the Sympathetic Reading}

Sympathetically read, section 1367 produces results that closely conform to the House Report's assertion that the statute was meant to preserve the jurisdictional requirements of the diversity statute. Recall that section 1367(a) provides for the assertion of supplemental jurisdiction only after "original jurisdiction" has attached to the claims in the plaintiff's complaint. This means that section 1367(a) does much of the work of preserving diversity by incorporating the rules of complete diversity into that term. While section 1367 (a) makes ancillary jurisdiction available after the rules of complete diversity have been satisfied and jurisdiction attaches, section 1367(b) creates exceptions to the scope of such ancillary jurisdiction to provide further protection for the rule of complete diversity. ${ }^{140}$

28 U.S.C. § 1367(b) (1994).

${ }^{110}$ Professors Tidmarsh and Transgrud have suggested an "alternate" reading of section 1367 (b) that would make its restrictive provisions inapplicable to cases such as Abbott Laboratories and Stromberg. See JAY TIDMARSH \& ROGER H. TRANSGRUD, COMPLEX LITIGATION AND THE ADVERSARY SYSTEM 355-56 (1998). In constructing their alternative, Professors Tidmarsh and Transgrud emphasize the language that limits the application of section 1367(b) to matters founded "solely on section 1332." Id. at 355. They note that Abbott Laboralories and Stromberg fail to satisfy the demands of complete diversity (as understood in cases decided before the statute became law) and could on this account fall outside section 1367(b) power such that the provisions in section 1367(b) do not come into play. Id. They also note that Snyder may present a different question from that in Zahn, inasmuch as none of the claims in Snyder came within the district court's original diversity jurisdiction. Id. at 356.

While this alternate reading focuses on the interplay between sections 1367 (a) and (b) and offers an interesting textual alternative to Abbott Laboratories and Stromberg, it differs in important respects from (and thus presents problems that do not plague) the sympathetic account. For example, the authors of the alternate reading struggle with what they see as a problem of tautology; if section 1367(a) permits less than complete 


\section{Preserving Zahn and Clark}

The sympathetic reading of section 1367 produces results wholly consistent with the legislative history and remains true to the language of the statute that Congress adopted. It thus dissolves the apparent tension, reported in cases such as Abbott Laboratories and Stromberg, between the supposedly clear results demanded by the literal text and the more modest claims in the legislative history. The Abbott Laboratories court mistakenly assumed that section 1367 (a) conferred a plenary grant of pendent jurisdiction on the federal courts, sitting in diversity. With such a grant in place, the court looked for exceptions in section 1367(b). Finding no exception there for claims brought by additional parties joined as plaintiffs under Rule 23, the Abbott Laboratories court concluded that Congress had unthinkingly overruled Zahn. The Stromberg court ascribed the same interpretive significance to the omission of the joinder of plaintiffs under Rule 20 in the course of its decision to regard section 1367 as a legislative overruling of the Clark rule.

Both courts erred in looking for an explicit exception on the face of section 1367(b). The exceptions appear instead in the requirement that "original jurisdiction" attach to the complaint of the plaintiffs in section 1367(a). The established rules of Zahn and Clark form a part of the jurisdictional requirements in diversity proceedings, and they were both incorporated into section 1367 (a) by reference. Congress thus had no reason to create any explicit exception in 1367(b) for claims by plaintiffs joined under either Rule 23 or Rule 20 . Jurisdiction over claims entailed in the joinder of additional plaintiffs had always required that those plaintiffs meet the amount-in-controversy requirement; the Zahn Court had explicitly refused to substitute the

diversity, then that leaves little for the diversity-linked provisions of section 1367 (b) to accomplish. Id. at 355. But if one sees section 1367 (b) as operating in the diversity context to cabin the doctrine of ancillary jurisdiction that comes into play only after the rules of original diversity jurisdiction have been satisfied (as in the sympathetic account), then 1367 (b) can still play a useful role. Similarly, the authors of the alternate reading worry that its emphasis on the need to satisfy the demands of original jurisdiction in 1367(a) would jeopardize the assertion of pendent jurisdiction in cases such as Gibbs. Id at 355-56. But reading section 1367(a) to require satisfaction of the demands of original jurisdiction (i.e., including the diversity rules) poses no threat to Gibbs once one recalls that the doctrine of pendent jurisdiction governs jurisdiction over related state-law claims joined with federal-question claims at the initial pleading stage. By preserving a conceptual distinction between pendent and ancillary jurisdiction and by recalling that pendent jurisdiction was (and may remain) simply unavailable in diversity, the sympathetic account avoids the pitfalls that Professors Tidmarsh and Transgrud identify. 
doctrine of pendent jurisdiction as the measure of such joinder and section 1367 seemingly preserves that choice in language preserving the rules of original jurisdiction.

Recent decisions, which explicitly reject the approach of Abbott Laboratories and Stromberg, provide some basis for optimism. In Leonhardt $v$. Western Sugar Co., the Tenth Circuit rejected the textualism of the two prior circuit decisions and concluded that Zahn remains good law. ${ }^{141}$ Citing an early draft of this Article, the court found that the text of section 1367 can be read "literally, and unambiguously" to incorporate the established rules governing the amount in controversy requirement for diversity jurisdiction. ${ }^{142}$ Some months later, in Meritcare Inc. v. St. Paul Mercury Insurance Co., the Third Circuit followed the Tenth Circuit's lead in rejecting the argument that section 1367 overrules Zahn. ${ }^{143}$ Although the Third Circuit found the Tenth's account of the text attractive, it ultimately based its decision on the legislative history (as had the Tenth) following the established rule that courts may defer to the legislative history in the face of ambiguities in the relevant text. ${ }^{144}$ Writing for the court, Judge Joseph Weis-the judge who had chaired the Federal Courts Study Committee and had represented the Judicial Conference in testimony about the statute in 1990 - made a compelling case that the history pointed to the preservation of the complete diversity rules.

\section{Preserving St. Paul}

The sympathetic reading also helps to expose the flaws in the Fourth Circuit's decision in Shanaghan v. Cahill, which read section 1367 as replacing the bright-line rule of St. Paul with the discretionary regime of section 1367 (c). ${ }^{145}$ Shanaghan proceeded by assuming that

141 160 F.3d 631, 640 (10th Cir. 1998) (concluding that "a literally and textually faithful reading of section 1367 (a) leads to the opposite conclusion from that of [ $A b$ bott Laboratories and Stromberg]").

${ }^{142} I d$ at 639 n.6, 640 .

${ }^{143} 166$ F.3d 214, 222 (3d Cir. 1999) (holding that section 1367 "preserves the prohibition against aggregation ... and thus maintains the traditional rules governing diversity").

${ }^{111}$ See id. at 222 (finding "sufficient ambiguity in [section 1367] to make resort to the legislative history appropriate ${ }^{n}$ ).

${ }^{145} 58$ F.3d 106, 112 (4th Cir. 1995) (holding that under section 1367 courts should "weigh convenience and fairness to both parties, as well as the interests of judicial economy" in deciding whether to retain jurisdiction over claims that fall below the amount-in-controversy requirements post-filing). 
the assertion of jurisdiction over claims aggregated to meet the jurisdictional threshold represented an assertion of supplemental jurisdiction under section 1367 (a). In truth, however, the federal courts have long applied their aggregation rules, not as a matter of supplemental jurisdiction, but as a matter of original jurisdictional analysis. ${ }^{146}$ Since the district court's power to hear the additional claims in Shanaghan did not, strictly speaking, derive from the grant of supplemental jurisdiction in section 1367 (a), the Fourth Circuit had no basis for bringing the discretionary regime of section 1367 (c) into play. ${ }^{147}$ Subsection (c), after all, permits the district court to refrain from exercising "supplemental," not original, jurisdiction. One might defend the outcome in Shanaghan as part of a considered review of the messy aggregation rules that govern original jurisdiction, but such a review would have to confront the controlling language of St. Paul more directly.

\section{Joinder in Alienage Cases}

The sympathetic reading also lays to rest the concern that section 1367 might have unwittingly foreclosed the assertion of pendent-party jurisdiction in alienage cases. ${ }^{148}$ The sympathetic reading teaches that

${ }^{146}$ See supra text accompanying notes 80-92 (discussing the distinction between aggregation rules and supplemental jurisdiction).

${ }^{117}$ For a well-reasoned rejection of Shanaghan that emphasizes the distinction between rules of original and supplemental jurisdiction in diversity matters, see WoldeMeskel v. Vocational Instruction Project Community Services, Inc., I66 F.3d 59, $64-65$ (2d Cir. 1999). But see Stevenson v. Severs, 158 F.3d 1332, 1334 (D.C. Cir. 1998) (following Shanaghan).

${ }^{148}$ It was Professor Freer who first argued that section 1367(b) flatly bars the use of pendent-party jurisdiction in alienage matters. See Freer, Life After Finley, supra note 3, at 47475 ("Although no one objects to pendent parties jurisdiction in [alienage cases], the statute outlaws its use, probably through inadvertence."). Professor Freer based his argument on the standard account of the Rule 20-reference in section 1367(b), which he took to apply to any attempt by plaintiffs to join additional defendants in matters within the scope of the jurisdiction conferred by section 1332. Seeing the reference to section 1332 as requiring complete diversity in alienage jurisdiction, as well as citizencitizen diversity, Professor Freer argued that the drafters had inadvertently eviscerated pendent-party jurisdiction. The drafters responded by arguing that section 1367(b) did not require such an outcome, pointing to the language at the end of the provision that forecloses supplemental jurisdiction only where inconsistent with the jurisdictional requirements of section 1332. See Rowe et al., A Reply, supra note 3, at 95455 (noting that after the passage of section 1367, federal courts remain free to "abolish the complete diversity rule for alienage jurisdiction"). According to the drafters, the statute simply refused to address the question of pendent parties in alienage, leaving the matter for resolution ultimately by the Supreme Court. See id. Compare Arthur \& Freer, The Disaster, supra note 3, at 978-81 (expressing doubt that the statute's text can be construed to leave the matter to judicial discretion), and Arthur \& Freer, Close 
the rules governing original jurisdiction in section 1332 matters remain intact, having been incorporated by reference into section 1367(a). Just as it preserves the rules of complete diversity in suits brought under section 1332(a)(1), section 1367(a) can be read sympathetically to preserve the role of the federal courts in giving shape to the rules of diversity in alienage cases under section 1332(a)(2). The rules of diversity in alienage matters have arisen by virtue of the federal courts' interpretation of the demands of original jurisdiction; ${ }^{149}$ they do not depend on the grant of supplemental jurisdiction in section 1367 (a) and do not come within the ambit of the restrictive language in section 1367(b). One can thus conclude that the statute preserves the status quo, just as its defenders have argued, without having to rely upon the language in section 1367(b) that relaxes its otherwise flat prohibition of the exercise of supplemental jurisdiction in specified situations under section $1332 .{ }^{150}$

\section{Supplemental Jurisdiction After Removal}

Early comments on the supplemental jurisdiction statute expressed a variety of concerns about its application to removed actions. ${ }^{151}$ Some observers, for example, questioned whether the statute would apply to removed cases at all, noting that the final version of

Enough, supra note 3, at 1012 (suggesting that courts interpreting the statute will not reach uniform conclusions regarding its application), with Rowe et al., $A$ Coda, supra note 3, at 998-99 (restating the claim of statutory agnosticism on the issue of alienage jurisdiction).

${ }^{149}$ The question of jurisdiction in alienage cases continues to evolve. See Rowe, supra note 8, at 59-61 (summarizing the rules of complete diversity that have emerged in section 1332(a) (2) cases but arguing that the rules make no sense and inappropriately restrict access to federal courts for aliens who may suffer bias in state courts). Professor Rowe acknowledges that the Supreme Court might yet rewrite these rules but considers the prospect unlikely and on that basis urges statutory reform. See id. at 61 . I have no quibble with the proposed reform and simply note that the current statute does not codify a complete-diversity rule for alienage matters but leaves the matter for resolution by the federal courts, and ultimately the Supreme Court, in the interpretation of the grant of original jurisdiction.

${ }^{150}$ For an account of the drafters' argument for the preservation of the status quo, relying upon the language in section 1367 (b), see supra note 148.

${ }^{151}$ See Freer, Life Afler Finley, supra note 3, at 485 (questioning whether the statute applies to removed cases); McLaughlin, supra note 1, at 949-52 (pointing out inequities to plaintiffs in removed actions if the statute is applied); Karen Nelson Moore, The Supplemental Jurisdiction Statute: An Important but Controversial Supplement to Federal Jurisdiction, 41 EMORY L.J. 31, 58-60 (1992) (discussing the statute's possible effects on removal cases). But see Joan Steinman, Supplemental Jurisdiction in \& 1441 Removed Cases: An Unsurveyed Frontier of Congress' Handiwork, 35 ARIZ. L. REV. 305, 308-10 (1993) (supporting the applicability of the statute). 
the statute dropped the specific reference to removed actions that had appeared in an early draft. ${ }^{152}$ Others expressed doubts that section 1367 (b) applied to actions removed on the basis of diversity; these doubts stemmed from the perception that removal jurisdiction depends upon the interaction of sections 1332 and 1441 and not "solely" on section 1332 as section 1367 (b) specifies. ${ }^{153}$ Still others worried about the unfairness that might result from the application of Kroger (and other restrictive rules of complete diversity) to plaintiffs who had not chosen the federal forum. ${ }^{154}$ Finally, some observers argued that the restrictive references to specific federal rules in section 1367(b) might have no application to litigation governed by state rules of procedure. ${ }^{155}$ Coupled with the standard account of section 1367 (a), the inapplicability of section 1367 (b) limits to removed cases appeared to have threatened some broadening of federal removal jurisdiction. ${ }^{156}$

Sympathetic interpretation can overcome these interpretive problems. The removal statute provides for removal by the defendants of any "civil action" of which the district courts have "original jurisdiction. ${ }^{.157}$ This test of original jurisdiction focuses on the plaintiff's state court complaint and considers whether its allegations meet the standards for the assertion of federal-question or diversity jurisdiction. ${ }^{159}$ It thus appears plausible to conclude that many of the same rules that govern the interplay between original and supplemental jurisdiction in actions instituted in federal court will also apply to actions removed

152 See, e.g., Moore, supra note 151 , at 59 (noting that the specific reference to removal cases dropped out during the drafting process).

${ }^{153}$ See Freer, Life After Finley, supra note 3, at 485 (arguing that removal jurisdiction is not founded solely on section 1332 and hence is not within the provisions of section 1367(b)); Moore, supra note 151, at 58 (same). But see Steinman, supra note 151, at 328 (considering and rejecting the argument for the inapplicability of 1367 (b) to removed cases).

${ }^{154}$ See Moore, supra note 151, at 58-59 (arguing that because the plaintiff in a removed case had initially chosen state court, the reasons for limiting supplemental jurisdiction emphasized in Kroger do not apply).

${ }^{155}$ See Steinman, supra note 151, at 330 (arguing that section 1367 does not apply to claims against persons made parties under state law prior to removal).

${ }^{136}$ See Steinman, supra note 8, at 103 (noting the possibility that section 1367 could be read to give federal courts jurisdiction over state-law class actions regardless of the citizenship and amounts in controversy of class members); Steinman, supra note 151, at 331 (concluding that section 1367(b)'s inapplicability to removed diversity cases could expand federal jurisdiction over class actions).

${ }^{157} 28$ U.S.C. $\$ 1441$ (a) (1994).

${ }^{15 s}$ See generally WRIGHT, supra note 19, at 224 (describing the rules that govern the determination of original and removal jurisdiction as "equated" and "linked" though not entirely coincident). 
to federal court. Whether the action begins in federal court or comes there on removal, the plaintiff's complaint must allege a civil action over which the district courts have original jurisdiction. By its terms, section 1367(a) applies to "any" such civil action and confers jurisdiction over related claims.

The parallel structure of the removal and supplemental jurisdiction statutes dissolves many of the uncertainties that others have identified. First, it appears quite clear, as the Supreme Court recently held, that the supplemental jurisdiction statute applies to removed actions. ${ }^{159}$ Second, the sympathetic reading of sections 1367 (a) and (b) essentially eliminates any concern that supplemental jurisdiction will unduly expand the scope of diversity jurisdiction in removed cases. If, as sympathetically construed, section 1367(a) incorporates the demands of complete diversity into its provision for the assertion of original jurisdiction, then the same rules that govern plaintiff's joinder and aggregation of parties and claims will apply to diversity matters initiated in and removed to district court. Only after the complaint satisfies such rules can the defendants remove and bring the doctrine of federal supplemental (ancillary) jurisdiction into play. As a consequence, section 1367(b)'s arguable inapplicability to actions in state court does not present an inordinate threat of broadened supplemental jurisdiction in removed diversity proceedings. Section 1367 (a), as we have seen, preserves the complete diversity rules and section 1367 (b) attempts to prevent ancillary jurisdiction from eroding them. ${ }^{160}$ Facing time constraints, most defendants will have removed the action before moving to implead or otherwise add parties whose joinder would present post-removal questions of ancillary jurisdiction. ${ }^{161}$

159 See City of Chicago v. International College of Surgeons, 522 U.S. 156, 165 (1997) (declaring that section 1367(a) applies with "equal force" to actions filed in and removed to federal court and that removed actions must satisfy the demands of original jurisdiction by definition).

${ }_{160}$ See supra text accompanying notes 93-108 (discussing section 1367(a)); text accompanying notes $130-39$ (discussing section 1367 (b)).

${ }^{161}$ The procedural rules governing removal require the defendants to file their notice of removal in district court no later than 30 days after they receive the initial pleading, or, if the action is not initially removable, within 30 days of the date on which it becomes so. See 28 U.S.C. $\$ 1446$ (b) (1994) (defining the period within which a defendant may remove an action to federal court). This requirement of speedy removal may explain why we have yet to see any cases that test the applicability of Kroger to a situation in which the plaintiff had already asserted claims against a nondiverse thirdparty before removal was effected. Cf. Steinman, supra note 8, at 104-05 (noting the absence of decided cases). Professor Steinman rightly notes the theoretical possibility of such cases. See id. 


\section{SYMPATHETIC TEXTUALISM AND JUDGE-MADE JURISDICTIONAL LAW}

So far, this Article has suggested that a sympathetic textualism can produce answers to discrete interpretive issues that fit well with the text of the statute and with the apparent understanding of Congress. This Part of the Article steps back from the particular issues to argue that the sympathetic reading of section 1367 also provides a stronger foundation on which to build a workable body of jurisdictional law. By reading section 1367 as a general grant of pendent and ancillary jurisdiction and as a decision otherwise to leave many jurisdictional issues untouched, the sympathetic account narrows the range of issues that the federal courts must regard as ones that Congress has definitively resolved. So read, the statute leaves a much broader range of issues for resolution by the federal courts, inviting them, in effect, to exercise the kind of pragmatic discretion that had long characterized judge-made jurisdictional law in the years preceding Finley. By preserving a role for the federal courts in the development of jurisdictional law, the sympathetic reading may avoid the stubborn textualism of Abbott Laboratories and the elaborate detail of the ALI Draft.

Of course, one can argue that Congress should, as a matter of first principles, play the lead role in the development of jurisdictional law. Congress, after all, bears responsibility for the decision to create inferior federal courts and has broad, if not unfettered, control over the scope of their jurisdiction. ${ }^{162}$ Many thoughtful observers have emphasized the importance of legislative control of jurisdiction and have worried that the courts will take too many liberties with their jurisdictional grants. Professor Martin Redish, for example, speaks for many when he argues that the federal courts have no principled basis on which to abstain from the exercise of jurisdiction that Congress has conferred upon them. ${ }^{163}$ Similar arguments for legislative primacy underlie criticisms of other doctrines in which the courts exercise

\footnotetext{
${ }^{162}$ For an account of the Madisonian Compromise and its embodiment in provisions of Article III that authorize but do not require Congress to create lower federal courts, see BATOR ET AL., supra note 78, at 11. See also Glidden Co. v. Zdanok, 370 U.S. 530,551 (1962) (describing the "great constitutional compromise" that authorized but did not obligate Congress to create inferior courts and noting that, once created, such courts remained "subject to jurisdictional curtailment").

163 See Martin H. Redish, Abstention, Separation of Powers, and the Limits of the Judicial Function, 94 YALE L.J. 71, 74 (1984) (arguing that abstention doctrines are inconsistent with American political theory).
} 
some discretion in defining what matters to hear. ${ }^{164}$

Among the most persuasive responses to this emphatic argument for legislative primacy, Professor David Shapiro has advanced a subtle and, to me, quite persuasive argument that the federal courts properly exercise a principled discretion in giving more particular content to general jurisdictional statutes. ${ }^{165}$ As Professor Shapiro notes, experience and tradition teach that the question whether to exercise jurisdiction and decide the merits of a particular dispute may defy general legislative definition; courts may enjoy functional advantages over the legislature in the necessary fine tuning. In suggesting the need for a dialogue between the courts and the legislature, ${ }^{166}$ Professor Shapiro argues for the widely held view that the business of defining the contours of judicial power represents a shared responsibility of the First and Third Departments. ${ }^{167}$

Certainly as a matter of history, much jurisdictional law has grown out of an unspoken partnership between the legislative and judicial branches of government. Congress has tended to provide relatively general jurisdictional grants and the Supreme Court has often played a fairly active role in shaping what we now think of as jurisdictional law. In a range of familiar cases, the Court has adopted interpretations of jurisdictional statutes that redefine the scope of federal power along lines scarcely visible in the legislative text. ${ }^{168}$ Many observers de-

161 Compate ALEXANDER M. BICKEL, The LEAST DANGEROUS BRANCH: THE SUPREME COURT AT THE BAR OF POLITICS 111-98 (1962) (defending the Court's use of justiciability doctrines to exercise discretion to avoid the merits of some controversial issues) with Gerald Gunther, The Subtle Vices of the "Passive Virtues"-A Comment on Principle and Expediency in Judicial Review, 64 COLUM. L. REv. 1, 25 (1964) (criticizing such discretionary avoidance as an unprincipled refusal to exercise jurisdiction that Congress has conferred on the Court).

${ }^{165}$ See David L. Shapiro, Jurisdiction and Discretion, 60 N.Y.U. L. REV. 543, 574 (1985) (arguing that courts are uniquely qualified on jurisdictional matters and should continue to have "measured authority" to decline jurisdiction).

${ }^{166}$ See id. at 577 (advocating a "productive dialogue").

${ }^{167}$ Professor Friedman has seconded Shapiro's call for dialogue between the courts and the legislature. See Barry Friedman, Dialogue and Judicial Review, 91 MrCH. L. REv. 577, 580-81, 668-69 (1993) (arguing against rigid separation of powers thinking and in favor of a dialogic approach to defining the judicial role). The Supreme Court's decision in Quackenbush v. Allstate Insurance Co., 517 U.S. 706, 731 (1996) (holding that Burford abstention can only be applied when "equitable or otherwise discretionary" relief is sought), reaffirmed the existence of the district court's equitable discretion to refrain from adjudicating particular disputes.

${ }^{16 s}$ See, e.g., Louisville \& Nashville R.R. Co. v. Mottley, 211 U.S. 149, 152-54 (1908) (holding that only those federal questions that appear on the face of the well-pleaded complaint can support the district court's assertion of arising-under jurisdiction); Osborn v. Bank of the United States, 22 U.S. (9 Wheat.) 738, 823 (1824) (holding that 
scribed the evolution of pendent and ancillary jurisdiction in the preFinley years as simply another illustration of the way in which the Court adapted jurisdictional law to take account of evolution in our understanding of the proper scope of a civil action. ${ }^{169}$

Practical considerations help to explain the role of the federal courts in making jurisdictional law. For a variety of reasons having to do with the nature of the political process, Congress simply has not done an effective job of keeping jurisdictional rules in good repair. ${ }^{170}$ Partly this congressional neglect reflects the inability of federal judges to play an institutionally effective role in securing jurisdictional legislation; partly it reflects the absence of well-organized interest group support; partly it reflects the relatively specialized nature of the subject matter and its inaccessibility to those without special competence in the subjects of civil procedure and federal courts. ${ }^{171}$ For all these reasons, Congress has been content, absent a crisis, to leave the elaboration of jurisdictional rules to the courts and similar specialists.

Even those who agree that the courts play an appropriate, and not just an inevitable, role in the development of jurisdictional rules may

Article III empowers Congress to assign federal trial jurisdiction over any claim in which a federal ingredient appears); Strawbridge v. Curtiss, 7 U.S. (3 Cranch) 267, 267 (1806) (holding, despite the absence of any clear constitutional or statutory requirement to that effect, that minimal diversity would not support federal trial jurisdiction).

${ }^{169}$ See Freer, supra note 2, at 55-60 (arguing that one can best rationalize the judgemade doctrines of pendent and ancillary jurisdiction as an interpretation of the statutory grant of original jurisdiction over "civil actions").

${ }^{170}$ For a summary of Congress's work on the judicial code of the United States, see WRIGHT, supra note 19, at 21-23 (describing the codifications of 1911 and 1948; noting the absence of any systematic updating of jurisdictional provisions; questioning the skill of the initial drafting and the quality of subsequent amendments; and opining that the time has come for the preparation of a new judicial code). In keeping with these concerns, Professor Wright supports, in his capacity as president of the ALI, the ALI's current judicial code revision project.

Although it has left jurisdictional rules in disrepair, Congress has taken an increased interest in the rule-making process in recent years. See Charles Gardner Geyh, Paradise Lost, Paradigm Found: Redefining the Judiciary's Imperiled Role in Congress, 71 N.Y.U. L. REv. 1165, 1169, 1187-91 (1996) (describing the period from 1973 to the present as one of heightened interaction between the judiciary and a Congress that is more willing to suspend and modify proposed procedural rules and expressing some optimism about the prospects for more effective interactions in the future).

${ }^{171}$ For a general account of the difficulties that arise from interactions between Congress and the judiciary in the course of the extrajudicial making of jurisdictional and procedural law, see Geyh, supra note 170. Professor Geyh persuasively argues that, despite some questions of self-interest, federal judges participate effectively in the lawmaking process because they are "extraordinary lawyers" who may understand the law and the implications of proposed reforms better than their legislative counterparts. $I d$ at 1219 (noting judges' unique expertise in matters such as procedure and judicial administration). 
view Finley as signaling the beginning of a new era. ${ }^{172}$ With its emphasis on the necessity for written authority, the Finley Court made what some have seen as a decisive break with the past. On this account, Finley brought to a close the free-wheeling jurisdictional days of Gibbs and inaugurated an era of close attention to statutory text. If the Finley Court foreswore the exercise of what the ALI Draft perceptively describes as pragmatic discretion in fashioning jurisdictional rules, ${ }^{173}$ then decisions such as that in Abbott Laboratories arguably proceed with appropriate deference to the command of their judicial superior in hewing closely to the textualist line.

The argument makes sense as far as it goes but the Finley decision proceeds upon the assumption that the ultimate responsibility for the content of jurisdictional law rests with Congress, not the Supreme Court. $^{174}$ In a world of avowed legislative supremacy, a decision by Congress to reestablish the partnership with the federal courts by delegating some responsibility for jurisdictional law to the federal courts would seemingly answer any doubts about the legitimacy of the judicial role. No constitutional principle forbids Congress from making such a delegation and it thus seems apparent that a post-Finley delegation of law-making authority from Congress to the federal courts would trump the new emphasis on literal textualism in Finley itself. $^{175}$

172 For the argument that Finley and section 1367 signal a new era of literal textualism in the law of supplemental jurisdiction, see Arthur \& Freer, The Disaster, supra note 3 , at 979 (arguing that the courts may not ignore the literal commands of a statute clear on its face); Freer, supra note 8, at 7 (arguing that the statutory model adopted in section 1367 "locks" future efforts into the same statutory model and precludes reliance on a regime of judicial discretion); and Purdue, supra note 16, at 74-75 (opposing development of the law through lower court decisions and arguing instead that the statute should provide clear and concrete answers, as in the model of Treasury Regulations). Cf. Rowe, supra note 8, at 54-58 (expressing general support for an interpretive approach that preserves a measure of judicial discretion and maintains a practical, working relationship between the federal courts and Congress but nonetheless concluding that certain features of the existing statute require a fix).

${ }^{173}$ For the AlI Draft's view of the demise of pragmatic discretion in judicial interpretation of jurisdictional grants, see supra notes 69-74 and accompanying text (describing the ALI Draft's approach to the statute).

${ }^{174}$ See Finley v. United States, 490 U.S. 545, 547-48 (1989) (arguing from implicit separation of powers grounds that the federal courts may not exercise jurisdiction without an appropriately clear grant of legislative authority).

${ }^{175}$ Consider, for example, Justice Frankfurter's famed dissent in Textile Workers Union v. Lincoln Mills, 353 U.S. 448, 460 (1957) (Frankfurter, J., dissenting). Although Frankfurter argued against the constitutionality of a provision of the Taft-Hartley Act that enabled federal courts to adjudicate suits for violation of collective bargaining agreements, he did so based upon his contention that the statute merely conferred 
Precisely such a delegation can be said to flow from the relatively open-ended grant of supplemental jurisdiction in section 1367. Read sympathetically, the statute supplies the grant of statutory authority that the Finley Court had identified as missing and otherwise attempts to reestablish the role of the federal courts in working out the details of supplemental jurisdiction. Three provisions in particular appear to restore a measure of judicial discretion. First, section 1367(a) incorporates the rules of original jurisdiction in diversity, rules that had previously developed through the exercise of some judicial discretion and remained in flux to some degree. Second, section 1367(b) establishes that the district courts may exercise ancillary jurisdiction in diversity matters only where they find it to be consistent with the jurisdictional principles of section 1332. This test of consistency incorporates the pragmatic analysis of the Kroger decision, where the Supreme Court balanced the threat to the complete diversity requirement against the arguments for litigant fairness in determining whether to hear the claim. ${ }^{176}$ Third, section 1367 (c) incorporates the rules governing the discretionary decline of jurisdiction that the Gibbs Court had earlier specified. ${ }^{177}$ The statute thus provides a framework within which the federal courts may continue to work out sensible jurisdictional rules.

The question of alienage jurisdiction provides an excellent illustration of the statute's operation as a jurisdictional framework. ${ }^{178}$ Ac-

jurisdiction on the federal courts to apply state-law rules of decision. See id. at 460-62 (arguing that the provision merely granted litigants access to a federal forum and did not authorize the development of substantive federal law in this area of labor disputes). The majority, however, had interpreted the statute as a substantive delegation of lawmaking power to the federal courts and had concluded that federal rules of decision would control. See id. at 451 (opinion of Douglas, J.) (finding that $\$ 301$ (a) of the Taft-Hartley Act "authorizes federal courts to fashion a body of federal law for the enforcement of these collective bargaining agreements"). While Frankfurter challenged the wisdom of accepting such a delegation without more guidance from Congress, $i d$. at 463-65 (Frankfurter, J., dissenting) he did not question Congress's constitutional power to effect such a delegation.

${ }^{176}$ For an overview of the Kroger litigation and the Court's decision to reject ancillary jurisdiction over the claims of the plaintiff against an impleaded third-party defendant, see supra notes 27-34 and accompanying text.

${ }^{177}$ See supra note 47 (quoting the Supreme Court's recent description of the function of section 1367(c)). Compare Executive Software N. Am., Inc. v. United States Dist. Court, 24 F.3d 1545, 1551-52 (9th Cir. 1994) (characterizing the exceptional circumstances test in section 1367(c) as narrower than its counterpart in Gibbs) with Brazinski v. Amoco Petroleum Additives, Inc., 6 F.3d 1176, 1182 (7th Cir. 1993) (describing the statute as codifying and not altering the judge-made principle of pendent jurisdiction).

${ }^{178}$ For a summary of the alienage question, see supra notes 148-50 and accompanying text. 
cording to most observers, the federal courts had yet to decide whether to allow pendent-party jurisdiction in alienage cases when section 1367 became law. ${ }^{179}$ It takes a great leap of interpretive faith to conclude that Congress addressed that question one way or another in section 1367. It makes far more sense to conclude that Congress simply left the matter in the hands of the courts through its provision in section 1367 (a) for the assertion of ancillary jurisdiction only after the demands of original jurisdiction had been satisfied. The statute does not specify the contours of that original jurisdiction and thus leaves the process of determining the proper boundaries between original and ancillary jurisdiction to the federal courts. ${ }^{180}$

Whatever one's view of the merits of that question, I believe that the preservation of a judicial role provides a better prescription for the long-term health of jurisdictional law than the rigorous textualism of Abbott Laboratories. Recall that in Abbott Laboratories, the Fifth Circuit not only refused to give effect to the legislative history but also quite deliberately refused to consider the "wisdom" of its conclusion that section 1367 had effectively, if unwittingly, overruled Zahn. ${ }^{181}$ In the end, the Abbott Laboratories court refused to take any responsibility for the jurisdictional rule that it applied; it simply declared the legislative text clear on its face and walked away. Perhaps the court meant to teach Congress a lesson, as Judge Pollak suggested in characterizing the opinion as an example of interpretive "gotcha."

179 See supra note 149 (noting the continued evolution of alienage jurisdiction).

${ }^{180}$ Some may wonder if the district courts would enjoy the same authority to rethink the rules of complete diversity as part of the process of elaborating the meaning of original jurisdiction in section 1367 (a). In my view, the question turns not on the meaning of the statutory language but rather on the nature of the district court's obligation to respect the unamended decisional law of the Supreme Court. The Court itself has created the rules that govern diversity of citizenship and amount-in-controversy and those decisions bind lower courts. In the alienage context, by contrast, the Court has yet to speak and the process of lower court development may continue. Of course, the lower courts may have reached a consensus that will reduce the likelihood of any further review by the Court. See Rowe, supra note 8, at 59, 61 (noting consensus among lower courts on the alienage jurisdiction question and viewing Supreme Court involvement as unlikely).

${ }^{131}$ See supra notes 50-55 and accompanying text (discussing the decision in Abbott Laboratories).

${ }^{182}$ According to Judge Pollak, writing in Russ v. State Farm Mutual Automobile Insurance Co., 961 F. Supp. 808 (E.D. Pa. 1997), the issue presented by the supposedly clear text of section 1367(b) was "almost impenetrable to any audience other than specialists in civil procedure in the federal courts." Id. at 819. In such a context, Judge Pollak suspects that most members of Congress would have relied upon the legislative history as the definitive extrinsic aid to statutory meaning. See id. (noting that the House Judiciary Committee issued a detailed report discussing section 1367). For the federal 
decision certainly proceeds upon the assumption that Congress has asserted control over the rules of supplemental jurisdiction and must deal with the consequences of its own mistakes. A similar assumption underlies the ALI Draft.

I suspect the law of federal jurisdiction will lose much if this rigorous textualism takes hold. ${ }^{183}$ Consider that the doctrine of supplemental jurisdiction-so essential that Congress acted quickly in the wake of Finley to provide the necessary statutory authority-evolved through the exercise of judicial discretion in the interpretation of jurisdictional law. One need not applaud each instance of this law to recognize that the rigorous textualism of Finley and Abbott Laboratories will ultimately displace the judicial role. The loss from such a pruning of judicial discretion could be considerable, leaving Congress with little guidance on jurisdictional issues and few incentives to approach them. One certainly has difficulty in seeing what would have moved Congress to work out the details of pendent-claim jurisdiction had the Court been unwilling to show the way in Gibbs.

\section{CONCLUSION}

I am unwilling to present the story of section 1367 as a morality play, in which the forces of good interpretation went to war with the forces of bad interpretation and lost. Reality rarely conforms to such simplistic assessments, and we have already witnessed some of the unfortunate consequences of rhetorical overkill. Yet it remains true that a statute Congress designed to achieve rather modest goals may well result in unsettling and confusing the law of supplemental jurisdiction to such an extent that it will require further congressional repairs. I

courts, to assert jurisdiction against the weight of such clear history was to say to Congress: "We know what you meant to say but you didn't quite say it. ... [B] etter luck next time." Id. at 820 (internal quotations omitted). Judge Pollak notes that under such a "gotcha" approach, Congress and the courts play antagonistic rather than coordinate roles in the government of the United States. See id. (drawing support for his decision from the need for Congress and the courts to work together as "parts of a single government").

${ }_{183}$ A good many observers share this concern. See Cooper, supra note 8, at 153 (supporting a regime of broadened judicial discretion and arguing that the detailed codification of the ALI cannot answer every question); Lilly, supra note 8, at 189 (suggesting that because "issues of supplemental jurisdiction arise in such varied contexts ... their resolution is ill-suited to statutory treatment"); Shapiro, supra note 8, at 218 (questioning the need for detailed codification and continuing to support development through case law). 
have presented an alternative, sympathetic interpretation in the hope that these results can still be avoided. 
